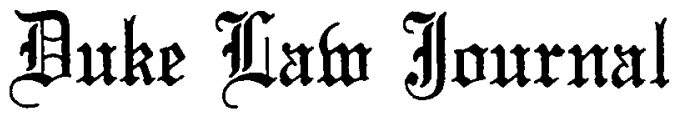

VOLUME 1980

DECEMBER

NUMBER 6

\section{THE OBLIGATIONS OF BANKS IN THE PUBLIC SECURITIES MARKETS}

\author{
Stephen J. Greenberg, ${ }^{*}$ William C. Mack, ${ }^{* *}$ \\ AND JEFFREY L. SCHULTE***
}

The boom in the securities markets in the 1960s gave companies ready access to capital. When the boom collapsed at the end of the decade, companies were forced to find new sources of long-term financing and new ways to raise capital for acquisitions. Increasingly, companies turned to banks. The stock-for-stock deal, the paradigm transaction of the 1960s, gave way to cash tender offers and leveraged buy-outs. Long-term bank financing largely replaced equity financing, which was no longer available to most companies. This fundamental change in the way companies financed acquisitions placed commercial banks in a central, often exposed, position in the public securities markets.

The financing of takeovers engenders securities law risks for a bank because of potential conflicts arising from the bank's possession of nonpublic information. For example, although banks owe a duty of confidentiality to their corporate customers, they are often under internal pressure to use confidential information in deciding how to respond

* B.A. 1963, Rutgers College; LL.B. 1966, University of Pennsylvania; Partner, Schnader, Harrison, Segal \& Lewis, Philadelphia, Pennsylvania.

** B.A. 1969, Brown University; J.D. 1974, University of Pennsylvania; Associate, Schnader, Harrison, Segal \& Lewis, Philadelphia, Pennsylvania.

*** B.A. 1971, Williams College; J.D. 1976, Yale University; Associate, Schnader, Harrison, Segal \& Lewis, Philadelphia, Pennsylvania.

THE FOLLOWING CITATION WILL BE USED IN THIS ARTICLE:

Memorandum of the Securities and Exchange Commission to the Senate Committee on Banking, Housing and Urban Affairs on Bank Fimancing of Tender Offers, Exhibit B to Letters, dated February 15, 1980, from Securities and Exchange Commission Chairman Harold M. Williams to Senators William Proxmire, Harrison A. Williams, Jr., and Paul S. Sarbanes, reprinted in 542 SEC. REG. \& L. REP. (BNA) A-2 (Special Supplement) (1980), hereinafter cited as SEC Memorandum. 
to a request for funds by a company seeking to acquire the customer. The bank's mere possession of confidential information about a target company that was formerly a customer may raise problems under the securities laws if the bank makes a loan to the acquirmg company. ${ }^{1}$

Another serious problem for a bank is hability for its trust department's misuse of material nonpublic information obtained by its commercial departınent. Banks owe duties both to the customers of their commercial departınents not to disclose confidential information and to the beneficiaries of trusts managed by their trust departments to act solely im the interest of those beneficiaries. ${ }^{2}$ To fulfill its imvestment duties to trust beneficiaries, a bank must use all the imformation it has, which perhaps includes nonpublic information. Its duties to commercial customers, however, require it to keep this same information in confidence. Banks have sought to avoid this conflict by establishing "Chinese Walls" to impede the flow of information between their commercial and trust departments, but it is highly questionable whether the Chinese Wall is an effective solution.

Finally, even when a bank does not itself run afoul of the securities laws, it can be liable as an aider and abettor of its customers' violations. ${ }^{3}$ The prospect of aider-and-abettor liability is enhanced as banks acquire greater knowledge about the activities of their customers.

This Article discusses the management of nonpublic information by banks trying to avoid liability arising from conflicting duties, and a bank's exposure to aider-and-abettor liability under the federal securities laws. It criticizes the Chinese Wall concept but concludes that the recent adoption by the Securities and Exchange Commission of an anti-fraud rule for tender offers makes the Chinese Wall a necessity for banks.

\section{MANAgement of Nonpublic Information}

\section{A. Conflicting Duties Relating to Nonpublic Information.}

Banks liaving access to nonpublic information about their borrowers may face one or inore of three conflicts:

1. Conflicting Duties Owed by the Bank in Transactions Involving Different Customers of the Commercial Department of the Bank. This conflict arises when one customer asks a bank to finance the takeover of another customer. The bank must determine whether and to what

1. See notes 10-16 infra and accompanying text.

2. See notes 65-70 infra and accompanying text.

3. See notes 154-74 infra and accompanying text. 
extent it may legitimately use nonpublic information obtained through its commercial lending relationship with the target company. Although the commercial loan officers will want to use all available information in deciding wliether the bank sliould finance the tender offer, the bank must be careful not to violate either its common law obligation of confidentiality to its borrower or the securities laws' restrictions on the use of nonpublic information. ${ }^{4}$

2. Conflicting Duties Owed to Customers of the Commercial and Trust Departments. In this most commonly recognized conflict, the bank must attempt to harmonize inconsistent duties: on the one hand, the bank must maintain confidentiality of nonpublic information about its cominercial borrowers, ${ }^{5}$ and on the other hand, it must satisfy its fiduciary obligation to act solely to benefit its trust department customers. ${ }^{6}$

3. Conflicting Duties Owed to Customers of the Trust Department and to the Securities Markets Generally. As imdicated above, a bank lias a fiduciary obligation to act solely in the interests of its trust department custoiners. Yet to avoid liability under the federal securities laws, a bank must also establish procedures to assure that the trust department does not trade on material nonpublic information obtained by the commercial department. ${ }^{7}$

These conflicts expose banks to potential liability for breach of fiduciary and other common law duties and for federal securities laws violations. Accordingly, banks must be sensitive to these conflicts and adopt procedures to control the use of material nonpublic information ${ }^{8}$ in their possession.

4. See notes 10-39 infra and accompanying text.

5. See notes 10-39 infra and accompanying text.

6. See notes 65-70 infra and accompanying text.

7. See notes 76-126 infra and accompanying text.

8. One of the principal difficulties faced by a bank attempting to control the use of material nonpublic information is to identify information in that category. The starting point is to distinguish the material from the nonmaterial. In TSC Indus. v. Northway, Inc., 426 U.S. 438 (1976), the Supreme Court held that a fact is material under the securities laws if there is a substantial likelihood that a reasonable investor would consider it important in making an investment decision. Id. at 449. A fact is not material merely because a sophisticated analyst might so regard it. See Securities and Exchange Commission, Institutional Investor Study Report, H.R. Doc. No. 92-64, 92d Cong., 1st Sess. 2540 (I971).

TSC involved the standard of materiality under rule $14 \mathrm{a}-9$ of the Securities and Exchange Commission's proxy rules. The actual formulation of the rule in the case is that a fact is material if there is "a substantial likelihood that a reasonable shareholder would consider it important in deciding how to vote." 426 U.S. at 449.

In formulating its standard of materiality, the Court considered the standards of materiality developed by the lower courts under section 10(b) of the Securities Excliange Act of 1934, 15 


\section{B. Possession, Use, or Disclosure of Nonpublic Information by a Bank's Commercial Department.}

The commercial department of a bank may acquire much nonpublic information from current or prospective customers whose securities are traded in the public securities markets. A customer may be required to provide nonpublic information pursuant to loan agreements that call for periodic disclosure of financial and corporate information or for notice to the bank of material events affecting the business or financial standing of the customer. In addition, the bank may acquire information through an audit of a customer's operations, financial records, and accounting procedures pursuant to a covenant permitting review at the discretion of the bank. Even without loan covenants requiring disclosure, commercial borrowers generally seek to mamtam good relations with their banks and thus are likely to volunteer nonpublic information.

Banks normally use this nonpublic information to stabilize their lending operations and assure the orderliness and adequacy of commercial credit. For example, a bank may use the imformation to develop lending expertise in a particular industry or geographic region. Indeed, the bank and its directors may even have an obligation to the bank's shareholders to use such information to the fullest extent possible in order to inaintain a competitive position in the commercial banking field and thus to protect the assets of the bank while achieving a reasonable return on the shareholders' equity investment. ${ }^{9}$ Yet the use of nonpublic information to remain competitive as a lender may conflict with a bank's obligation to its borrower not to disclose or inisuse confidential imformation obtained through the lending relationship.

U.S.C. $\S 78 \mathrm{j}$ (b) (1976), and rule 10b-5, 17 C.F.R. $\$ 240.10 \mathrm{~b}-5$ (1980), promulgated thereunder. See 426 U.S. at 445 n.8. It is clear from the Court's analysis that its definition of materiality applies to provisions of the federal securities laws other than the proxy rules, and lower courts have so read the TSC decision. See, e.g., Lilly v. State Teachers Retirement Sys., 608 F.2d 55 (2d Cir. 1979) (applying the TSC standard under rule 10b-5), cert. denied, $100 \mathrm{~S}$. Ct. 2159 (1980); Seaboard World Airlines, Inc. v. Tiger Int'l, Inc., 600 F.2d 355 (2d Cir. 1979) (applying the TSC standard under section 14(e)).

The TSC standard attempts to introduce an objective criterion into the concept of materiality: the impact of a fact on a reasonable investor. Nevertheless, materiality is in the eye of the beholder. In each case presenting this issue, the trier of fact undoubtedly will have his own idea of whether a particular fact is material. Accordingly, as a practical matter, it is impossible before litigation to distinguish perfectly the material from the immaterial.

After a bank has decided that a particular item of information concerning a company is material, it must ascertain whether the information has been publicized. To do this, the bank must question management, scrutimize the company's filings with the Securities and Exchange Commission, and examine the company's press releases.

9. See SEC Memorandum 6 n.13. 
1. Possession of Nonpublic Information Obtained from a Commercial Customer. Large commercial banks lend to many companies. Because banks now play a more important role im financing cash tender offers and other forms of acquisition, the likelihood has imcreased that a bank may be financing the acquisition of a past or present customer.

Mere possession of nonpublic information about a customer does not itself disqualify a bank from financing the acquisition. Two recent cases have considered the argument that a bank possessing nonpublic information about a commercial department customer violates a duty to that customer inerely by financing a proposed acquisition: American Medicorp, Inc. v. Continental Illinois National Bank \& Trust Co., ${ }^{10}$ and Washington Steel Corp. v. TW Corp. ${ }^{11}$ In American Medicorp a federal district court refused to impose a blanket ban on a bank financing the takeover of one of its custoniers. The bank's lending activities should not be automatically constrained, the court stated, simply because the bank possesses confidential information about the target company.

In Washington Steel, Talley Industries and its subsidiary, TW Corporation, attempted to acquire Washington Steel Corporation by a tender offer financed by Chemical Bank. Chemical had made loans to botlı Washington and Talley, and was a registrar for Washington's cominon stock. ${ }^{12}$ In connection with its loan to Washington, Chemical Bank had received nonpublic information from Washington that included cash flow and earnings projections. Washington sued to enjoin the tender offer, claiming, inter alia, that Chemical had violated a fiduciary duty not to act adversely to Washington's interests. According to Washington, the duty arose from the prior banking relationship between the parties and the bank's receipt of confidential information froin Washington. Washington argued that when a bank possesses confidential information about a customer, the bank violates per se a duty to tlie customer by financing its potential acquirer.

The district court in Washington Steel, contrary to the American Medicorp court, concluded that the bank's possession of confidential information about the target company created a fiduciary obhigation that the bank had ignored in considering a loan to the offeror. ${ }^{13}$ The

10. 475 F. Supp. 5 (N.D. Ill. 1977) (an order denying a preliminary injunction).

11. 465 F. Supp. 1100 (W.D. Pa.), rev'd and remanded, 602 F.2d 594 (3d Cir. 1979).

12. A registrar of a corporation is responsible for maintaining the coinpany's stock register, which shows the record ownership of outstanding shares of the company's stock.

13. The court concluded:

Chemical Bank was well aware of its fiduciary obligation to Plaintiff Washington Steel and Defendants Talley and TW, and as a matter of law the Defendant Chemical Bank had a duty not to act adversely to the interests of Plaintiff Washington Steel under the circuinstances; and further, the Defendant Cheinical Bank had a duty to disclose all relevant facts which Chemical Bank knew or should have known that were relevant to 
Court of Appeals for the Third Circuit reversed this comprehensive rule on appeal. ${ }^{14}$ The novelty of the proposed duty and the public policy of encouraging the free flow of capital caused the court to reject the per se rule. The court reasoned that the per se rule could destroy or drastically attenuate the access to banks on which capital venture funding depends. If a bank could not lend to a company seeking to acquire a customer about which the bank possessed confidential information, any company wishing to avoid a takeover could do so by obtaining loans from major banks and providing them with nonpublic imformation. The court concluded that the per se rule would prevent those banks not only from financing takeovers but also from financing ordinary competition. ${ }^{15}$ The prospect of this restriction on bank financing proinpted the Third Circuit to endorse the holding of the American Medicorp court. ${ }^{16}$

2. Disclosure to One Commercial Customer of Nonpublic Information Obtained from Another Commercial Customer. While mere possession of confidential information about a target company does not trigger liability, the disclosure of it to the acquiring company during the bank's financing of the acquisition would result in liability for the bank. In Humana, Inc. v. American Medicorp, Inc. ${ }^{17}$ the court stated in dictuin that a fiduciary relationship exists between bank and borrower that prohibits the disclosure of confidential information obtained through the lender-borrower relationship. ${ }^{18}$ The court concluded that in light of this special relationship, the potential for conflict would best be avoided by the "voluntary behavior of the bank itself."19

allowing Plaintiff Washington Steel to make an informed decision as to whether or not Plaintiff Washington Steel should allow a dual agency relationship with adverse partics to continue.

465 F. Supp. at 1105.

14. 602 F.2d 594 (3d Cir. 1979).

15. Id. at 599-601. See also Microdot, Inc. v. Irving Trust Co., Index No. $1123-76$ (N.Y. Sup. Ct. Jan. 21, I976) (case withdrawn); Panel Discussion, Financing and Other Aspects of Cash Tender Offers, 32 Bus. LAw. 1415, I421 (1977) (remarks of Mr. Siminons characterizing the assertion of the per se rule in the Microdot complaint as "sheer nonsense"); Note, Bank Financing of Involun. iary Takeovers of Corporate Customers: A Breach of a Fiduciary Duty?, 53 Notre DAME LAW. 827,835 (1978).

16. 602 F.2d at 601 .

17. [1977-I978 Transfer Binder] FED. SEC. L. REP. (CCH) I 96,286, at 92,823 (S.D.N.Y. 1978).

18. Id. at 92,829; see SEC Memorandum 6. See also Harnischfeger Corp. v. Paccar, Inc., 474 F. Supp. 1151 (E.D. Wis. 1979); Herzel \& Rosenberg, Loans 10 Finance Tender Offers: The Bank's Legal Problems, 96 Banking L.J. 676, 678-79 (1979); Mendez-Penate, The Bank "Chinese Wall": Resolving and Contending with Conficts of Duties, 93 BANkING L.J. 674, 676 (1976).

19. [1977-1978 Transfer Binder] FED. SEC. L. REP. at 92,829. 
Federal securities laws also limit a bank's freedom to disclose information about its customers. For example, a bank's disclosure of nonpublic information about a target company to a tender offeror might constitute a tipping violation ${ }^{20}$ under section $10(b)^{21}$ of the Securities Exchange Act of 1934 (the 1934 Act) ${ }^{22}$ and rule 10b-5.23 Tipping has been defined as the transmission of nonpublic information by one having access to such information to a person whom the tipper can foresee will trade upon that information. ${ }^{24}$

The Securities and Exchange Commission addressed this problem in reponse to a request from Senators Proxmire, Sarbanes, and Williams for comment on the need for new securities legislation. ${ }^{25}$ The Commission expressed the view that a bank violates rule $10 \mathrm{~b}-5$ as a tipper by disclosing to a tender offeror nonpublic information about the target company, if the offeror actually purchases securities without making the information public. ${ }^{26}$ The Commission noted, however, that if the offeror discontinued the takeover attempt after receiving the nonpublic information, liability under rule $10 \mathrm{~b}-5$ would be less clear because the disclosure probably would not be "in connection with" either the purchase or sale of a security under rule $10 \mathrm{~b}-5 .^{27}$

20. See SEC v. Texas Gulf Sulphur Co., 401 F.2d 833 (2d Cir. 1968) (en banc), cert. denied, 394 U.S. 976 (1969), on remand, 312 F. Supp. 77 (S.D.N.Y.), aff'd in part and rev'd in part, 446 F.2d 1301 (2d Cir.), cert. denied, 404 U.S. 1005, on remand, 331 F. Supp. 671 (S.D.N.Y. 1971).

21. 15 U.S.C. $\S 78 \mathrm{j}(\mathrm{b})(1976)$.

22. 15 U.S.C. $\$ \$ 77 \mathrm{~b}-77 \mathrm{e}, 77 \mathrm{j}, 77 \mathrm{k}, 77 \mathrm{~m}, 77 \mathrm{o}, 77 \mathrm{~s}, 78 \mathrm{a}-78 \mathrm{o}, 78 \mathrm{p}-78 \mathrm{hh}$ (1976).

23. 17 C.F.R. $\$ 240.10$ b-5 (1980).

24. In SEC v. Lum's, Inc., 365 F. Supp. 1046 (S.D.N.Y. 1973), the court described the tipping violation as follows:

It has been the rule of this Circuit for some time that it is a violation of Section $10(\mathrm{~b})$ and Rule $10 \mathrm{~b}-5$ for a person liaving access to material non-public corporate information to trade upon or transmit such information under circumstances where it is foreseeable that it will or miglit be traded upon and a purcliase or sale is in fact executed.

Id. at 1057 (citations omitted).

In its recent decision im Chiarella v. United States, 445 U.S. 222 (1980), the Supreme Court may have narrowed the rule in SEC v. Lum's, Inc., by suggesting there must be a breach of duty by a corporate insider as a prerequisite to finding liability for a tipping violation:

"Tippees" of corporate insiders have been held liable under $\$ 10(b)$ because they have a duty not to profit from the use of inside information that they know or should know is confidential and know came from a corporate insider . . . The tippee's obligation has been viewed as arising from his role as a participant after the fact in the insider's breach of a fiduciary duty.

Id. at $230 \mathrm{n} .12$ (citations omitted). When a bank receives nonpublic information from a customer under circumstances that do not constitute a breach of an insider's fiduciary duty, such as where a member of the customer's managennent provides the information in connection with obtaining a loan from the bank, it has now become questionable whether a bank that discloses this information to a third party would be liable under the Supreme Court's description of tipping.

25. See texi accompanying notes $49-50$ infra.

26. SEC Memorandum 6.

27. Id. Rule $10 \mathrm{~b}-5$ is restricted to fraud "in connection with the purchase or sale of any security." Section 14(e) is limited to fraud "in connection with any tender offer." 
The Supreme Court's recent decision im Chiarella v. United States $^{28}$ casts doubt on the potential hability of a bank under rule 10b5 in the circumstances discussed above. In Chiarella the Court reversed the conviction under section 10(b) of the 1934 Act of an employee of a financial printer who had purchased securities on the basis of nonpubhic inforination acquired through his job. The purchases were made in the public securities markets without communication between Chiarella and his sellers; Chiarella thus made no misrepresentations to the sellers. The only conduct for which he could be liable under rule 10b-5 was his failure to disclose wliat he knew. The failure to disclose, however, would have violated rule $10 \mathrm{~b}-5$ only if Chiarella had an obhigation to reveal material facts. The Court formulated a test to determme whether a buyer or seller has such an obligation: the buyer or seller must be either a corporate imsider or a fiduciary of the person with whoin he deals. Simce Chiarella was found not to have been a corporate imsider or a fiduciary, he owed his sellers no duty of disclosure. ${ }^{29}$ The Chiarella Court suggested that it did not intend to overrule cases holding tippees of corporate insiders liable for trading on nonpublic information. The Court viewed tippee liability as beimg premised on participation "after the fact" in an insider's breach of a fiduciary duty. ${ }^{30}$

Chiarella makes the determination of insider status crucial to liability under rule 10b-5. For a bank, this issue must be decided by a thorough review of the banking relationship in each case. One clear indication of insider status is the presence of a bank officer or director on the board of directors of the target company. Such a relationship played a sigmificant role in one suit agamst a bank that financed a takeover attempt. ${ }^{31}$ Another factor that might create insider status is the presence of a provision frequently included in loan documents that requires the borrower to inamtain management satisfactory to the bank. Yet even without such a direct relationship with the management of the target company, a bank could conceivably be deemed to be an insider solely as a result of the numerous restrictive covenants that commercial

28. 445 U.S. 222 (1980).

29. Id. at 232-33. See Black v. Shearson, Hammill \& Co., 266 Cal. App. 2d 362, 72 Cal. Rptr. 157 (1968), in which the court held that under California law an intentional failure to disclose a material fact in a securities transaction is actionable fraud if there is a fiduciary relationship giving rise to a duty to disclose. The court held that a stockbroker owes such a duty to his customers. See also General Time Corp. v. Talley Indus., 403 F.2d 159, 164 (2d Cir. 1968), cert. denied, 393 U.S. 1026 (1969).

30. 445 U.S. at 230 n.12. See note 24 supra.

31. See the complaint in Microdot, Inc. v. Irving Trust Co., Index No. 1123-76 (N.Y. Sup. Ct. Jan. 21, 1976) (case withdrawn). 
loan agreements normally contain. No cases provide direct guidance, but before Chiarella the Securities and Exchange Commission concluded, on the basis of cases involving departmentalized securities firms, that the class of imsiders extends beyond officers, directors, and significant shareholders to include "anyone having a special relationship to the company."32

The Securities and Exchange Commission recently clarified the issue of a bank's liability for disclosing nonpublic information in a tender offer by adopting rule $14 \mathrm{e}-3^{33}$ in response to the Chiarella decision. ${ }^{34}$ The purpose of the rule, which generally prohibits any person

32. INSTITUTIONAL INVESTOR STUDY REPORT, supra note 8, at 2539.

33. 45 Fed. Reg. $60,410,60,418$ (1980) (to be codified in 17 C.F.R. $\$ 240.14 e-3$ ). Before adopting rule 14e-3 the Commission had proposed an anendment to section 14 of the 1934 Act to prohibit banks from disclosing nonpublic information obtamed from a target company to a tender offeror or any other person, regardless of whether the offer goes forward, unless the target company consents to the disclosure. Section 14(e), 15 U.S.C. $\$ 78 n(e)$ (1976), provides in part:

It shall be unlawful for any person to make any untrue stateincnt of a material fact or omit to state any material fact necessary in order to inake the stateinents made, in the light of the circumstances under which they are inade, not misleading, or to engage in any fraudulent, deceptive, or manipulative acts or practices, in connection with any tender offer or request or mvitation for tenders, or any solicitation of security holders in opposition to or in favor of any such offer, request, or invitation.

The Commission viewed section 14 (e) as sufficient to prohibit banks from disclosing nonpubhic information in tender offers if the tender offers went forward, but recognized the argument that, if a tender offer is discontmued as a result of disclosure, the disclosure may not have been made "in connection with" a tender offer under section 14(e). SEC Meinorandum 6. The amendment was thus proposed specifically to extend the reacl of section 14 to the case $\mathrm{m}$ which a tender offer is discontinued as a result of the disclosure of information. SEC Memoranduin 11.

The text of the proposed amendment is as follows:

It shall be unlawful for any person who lends all or any part of the consideration to be used for the purchase of securities pursuant to a tender offer for, or request or imvitation for tenders of, any class of equity security, to disclose any inaterial, non-pubhic information obtained by such person, from the issuer of such class of equity security, to any other person, unless authorized by such issuer.

SEC Meinorandum 10.

34. Rule $14 \mathrm{e}-3$ represents a significant limitation on the holding of Chiarella as it pertains to tender offers, as Walton v. Morgan Stanley \& Co., 623 F.2d 796 (2d Cir. 1980), demonstrates. Kennecott Copper Corporation engaged Morgan Stanley to find a company that Kennecott could acquire. Morgan Stanley approached Olinkraft Corporation and obtained confidential earnings projections on the understanding that they would be used only for a possible Kennecott tender offer. After Kennecott decided not to bid for Olinkraft, Texas Eastern Corporation announced an offer to acquire control of Olinkraft. Expecting that Texas Eastern would make an even higher offer, Morgan Stanley purchased approximately 150,000 shares of Olinkraft and then disclosed the earnings projections it liad obtamed to Johns-Manville Corporation, which made a higher bid for Olinkraft and eventually obtamed control of the company. Shareholders of Olinkraft sued Morgan Stanley for the profit it inade on the 150,000 shares. The United States Court of Appeals for the Second Circuit affirmed dismissal of the complaint on the ground that no fiduciary relationship existed between Olinkraft and Morgan Stanley. Citing the Supreme Court decision in Chiarella, the Wallon court stated that the "doctrine that a duty to disclose or refram froin trading arises from a specific relationship between two parties-and not sinply from the fact that some investors have inore information than others-is now established in both state and federal law." 623 F.2d at 799 n.6. 
from disclosing nonpublic information relating to tender offers, is twofold: to establish a "disclose or abstain froin trading" rule for tender offers $^{35}$ and to create an explicit anti-tipping rule for tender offers under section $14(\mathrm{e}) .^{36}$

Under the rule, a bank cannot disclose to a third person nonpublic information obtained from a custoiner if a tender offer for the customer's stock has been made or is about to commence. Disclosures inade in good faith to the officers, directors, partners, einployees, or advisors of the offeror, however, are not prohibited by the rule. In its release accompanying the adoption of rule $14 \mathrm{e}-3$, the Commission

Under rule 14e-3, however, the case would come out differently. Morgan Stanley's purchase of Olinkraft shares after Texas Eastern's bid had begun and while Morgan Stanley possessed nonpublic information obtained from Olinkraft would violate rule 14e-3(a). In addition, the disclosure of the nonpublic information to Johns-Manville might have violated rule 14e-3(d).

35. The text of rule $14 \mathrm{e}-3(\mathrm{a})$ is as follows:

(a) If any person has taken a substantial step or steps to commence, or has commenced, a tender offer (the "offering person"), it shall constitute a fraudulent, deceptive or manipulative act or practice within the meaning of section 14(e) of the Act for any other person who is in possession of material information relating to such tender offer which information he knows or has reason to know is nonpublic and which he knows or has reason to know has been acquired directly or indirectly from (1) the offering person, (2) the issuer of the securities sought or to be sought by such tender offer, or (3) any officer, director, partner or employee or any other person acting on behalf of the offering person or such issuer, to purchase or sell or cause to be purchased or sold any of such securities or any securities convertible into or exchangeable for any such securities or any option or right to obtain or to dispose of any of the foregoing securities, unless within a reasonable time prior to any purchase or sale such information and its source are publicly disclosed by press release or otherwise.

45 Fed. Reg. 60,418 (1980) (to be codified in 17 C.F.R. $\$ 240.14 e-3$ (a)) (emphasis added).

36. The text of rule $14 \mathrm{e}-3(\mathrm{~d})$ is as follows:

(d)(1) As a means reasonably designed to prevent fraudulent, deceptive or manipulative acts or practices within the meaning of section 14(e) of the Act, it shall be unlawful for any person described in paragraph (d)(2) of this section to cominunicate material, nonpublic imformation relating to a tender offer to any other person under circumstances in which it is reasonably foreseeable that such communication is likely to result in a violation of this section except that this paragraph shall not apply to a communication made in good faith,

(i) To the officers, directors, partners or employees of the offering person, to its advisors or to other persons, mvolved im the planning, financing, preparation or execution of such tender offer,

(ii) To the issuer whose securities are sought or to be sought by such tender offer, to its officers, directors, partners, employees or advisors or to other persons, involved in the planning, financing, preparation or execution of the activities of the issuer with respect to such tender offer, or

(iii) To any person pursuant to a requirement of any statute or rule or regulation promulgated thereunder.

(d)(2) The persons referred to in paragraph (d)(1) of this section are:

(i) The offering person or its officers, directors, partners, employees or advisors;

(ii) The issuer of the securities sought or to be sought by such tender offer or its officers, directors, partners, employees or advisors;

(iii) Anyone acting on behalf of the persons im paragraph (d)(2)(i) of this section or the issuer or persons im paragraph (d)(2)(ii) of this section; and

(iv) Any person in possession of material information relating to a tender offer which information he knows or has reason to know is nonpublic and which he knows or has reason to know lias been acquired directly or indirectly from any of the above.

Id. (to be codified in 17 C.F.R. $\$ 240.14 \mathrm{e}-3(\mathrm{~d})$ ). 
states that the purpose of this exception is to permit the offeror to communicate information to persons involved in the tender offer. Even if it is assumed that a bank may take advantage of the exception, however, it has the burden of proving that it communicated the information in good faith. If the bank knows or has reason to know that the persons to whom it discloses information will violate rule $14 \mathrm{e}-3$, the bank is a tipper in violation of rule $14 \mathrm{e}-3(\mathrm{~d})$, and the person who acquires the information and trades on it is a tippee in violation of rule $14 \mathrm{e}-3(\mathrm{a}) .^{37}$

Rule $14 \mathrm{e}-3$ will probably be challenged as an invahd exercise of the Commission's ruleinaking authority under section $14(\mathrm{e}) .^{38}$ If it survives the challenge, the rule will prohibit a bank from disclosing nonpublic information about the target to the offeror even if the disclosure is made in good faith. ${ }^{39}$

37. 45 Fed. Reg. 60,410, 60,417 (1980) (release accompanying the promulgation of rule 14e3). Presumably, shareholders of the target company would have an implied cause of action against a bank that violated rule $14 \mathrm{e}-3$ provided that they could prove damages in connection with the sale of their shares to a recipient of the nonpublic information. See generally Comment, Implied Rights of Action in Federal Legislation: Harmonization within the Statutory Scheme, 1980 Duke L.J. 928.

38. The Securities and Exchange Commission's rulemaking authority comes from section 14(e) of the 1934 Act, 15 U.S.C. $\$ 78 n(e)$ (1976). Section 14(e) provides in pertinent part: "The Commission shall, for the purposes of this subsection, by rules and regulations define, and prescribe means reasonably designed to prevent, such acts and practices as are fraudulent, deceptive, or manipulative." Undoubtedly, the vahdity of rule $14 \mathrm{e}-3$ will be questioned. The Supreme Court in Chiarella described section 10(b) of the 1934 Act in the following terms:

Section $10(b)$ is aptly described as a catch-all provision, but what it catches must be fraud. When an allegation of fraud is based upon nondisclosure, there can be no fraud absent a duty to speak. We hold that a duty to disclose nnder $\S 10(b)$ does not arise from the mere possession of nonpublic market information.

445 U.S. at 234-35. A recent comment on the Chiarella decision noted: "The Court left hittle doubt that the duty to disclose enforced by rule 10b-5 must be found outside the securities laws." Koeltl \& Kubek, Chiarella and Market Information, 13 Rev. SEC. REg. 903, 906 (1980).

Section 14(e) of the 1934 Act, under which rule 14e-3 was adopted, inakes it unlawful to engage in fraudulent, deceptive, and manipulative acts im connection with a tender offer. While section 14(e) requires the Commission to adopt rules and regulations to define and prescribe means to prevent such acts and practices, it is difficult to understand how this provision gives the Commission the authority to define fraud under $14(\mathrm{e})$ in a manner that is fundamentally mconsistent with the concept of fraud under section 10(b) as defined by the Supreme Court. As the Court stated in Emst \& Ernst v. Hochfelder, 425 U.S. 185, 213 (1976), "The rulemaking power granted to an administrative agency charged with the administration of a federal statute is not the power to make law." Cf. Aaron v. SEC, $100 \mathrm{~S}$. Ct. 1945 (1980) (the SEC unsuccessfully argued that proof of scienter is not required in an enforcement action by the Commission under section 10(b) even though it is required in a private cause of action for damages under the same provision).

39. The good-faith exception permits commumcations only to the offeror's officers, directors, employees, and advisors, and not to the offeror itself. Compare rule 14e-3(d)(1)(ii) (permitting communication to the issuer whose securities are sought im the tender offer and its officers and directors, partners, employees, and advisors) with rule $14 \mathrm{e}-3(\mathrm{~d})(1)(\mathrm{i})$ (permitting communication only to the officers, directors, partners, employees, and advisors of the offeror). The good-faith standard makes the bank a virtual guarantor of the actions of those to whom the communication was made. 
Therefore, in light of the potential for liability, a bank that is considering financing a tender offer or other acquisition of the securities or assets of one of its corporate borrowers should avoid disclosing nonpublic information to the acquiring company. Even if the bank takes appropriate precautions, lowever, it must recognize that once it decides to finance an acquisition involving two of its customers the bank will likely be joined in the securities litigation that invariably accompanies contested tender offers. The fact that the takeover involves two of its custoiners would almost certainly provoke one customer to charge the bank witl a conflict of interests.

\section{Internal Use of Nonpublic Information Obtained from One Cus-} tomer in a Transaction with Another Customer. Although there is little doubt that a bank should not disclose confidential information about one custoiner to another, the more difficult question is whether a bank itself may use such information when deciding whether to lend to a customer otler than the one to which the information relates. This problein inost commonly occurs when one customer of a bank proposes to acquire another of the bank's customers. The federal courts that have considered this question have not agreed. The Court of Appeals for the Third Circuit discussed extensively the propriety of a bank's internal use of confidential information in Washington Steel Corp. $v$. $T W$ Corp $^{40}$ In dictum, the court declined to adopt the view that a bank violates a duty to a customer when it uses information received from that custoiner in deciding whether to inake a loan to another prospective borrower. ${ }^{41}$ The court reached this conclusion for the same policy reason that led it to dismiss the per se rule against financing takeovers of customers: the potential restrictions on the availability of capital. ${ }^{42}$ The court reasoned that banks would have to act blindly, perhaps in derogation of their duties to depositors, if they were not permitted to consider all the information at their disposal before lending. To avoid this problem, banks might refram from lending to any companies that seek to acquire the stock of other bank custoniers. Because either alternative impedes "the free flow of funds," the court of

40. 602 F.2d 594 (3d Cir. 1979).

41. Id. at 603. The court also stated:

Of course, we intinate no view on whether a bank may be foreclosed from disseminating confidential information to a separate bank department, such as the trust department, whose function it is to recommend particular investments to its chents. Such dissemination of insider information arguably might violate Section 10(b) of the Securities and Exchange Act of 1934 and the S.E.C.'s Rule 10b-5.

Id. (emphasis in original). For a discussion of this problem, see text accompanying notcs 63-112 infra.

42. See text accompanying note 15 supra. 
appeals declined to hamper internal bank communications. ${ }^{43}$

Other federal courts, however, do not share the Third Circuit's view. For example, in American Medicorp, Inc. v. Continental Illinois National Bank and Trust Co. ${ }^{44}$ Judge McMillen strongly imphed that a bank may not use nonpublic information obtained from a customer when financing a second corporation's attempt to acquire that customer. ${ }^{45}$ Similarly, in Humana, Inc. v. American Medicorp, Inc. ${ }^{46}$ a related case, Judge Lasker agreed with Judge McMillen that a fiduciary or confidential relationship between a bank and its customer precludes the bank from disseminating or using nonpublic information about the customer for "improper purposes." 47 The Securities and Exchange Commission apparently also believes that a bank's internal use of nonpublic information received from and concerning its borrower breaches a common law duty the bank owes to the borrower. ${ }^{48}$

Senators Proxmire, Sarbanes, and Williams recently questioned the use of nonpublic information by banks in tender offers. In a letter to the cliairman of the Securities and Exchange Commission, ${ }^{49}$ the senators expressed concern about the potential for banks to exploit confidential information, particularly in tender offer financing. They also inquired about the coverage of the securities laws in this area, and solicited the chairman's suggestions for any necessary amendments. ${ }^{50}$

In response, Chairman Williams wrote, "The Commission beheves that the federal securities laws should expressly regulate the use of in-

43. 602 F.2d at 603.

44. 475 F. Supp. 5 (N.D. Ill. 1977) (denying a preliminary injunction).

45. We ... find that a bank is not precluded under all circunstances from making a loan to facilitate the attempted takeover of a customer. If it does not rely on the confidential information of its customers in its files, we believe that a bank is free to deal with any customer who comes to it. Id. at 8.

46. [1977-1978 Transfer Binder] FED. SEC. L. REP. (CCH) I 96,286, at 92,823 (S.D.N.Y. 1978).

47. Id. at 92,829 .

48. In deciding whether to finance a cash tender offer, a bank may be in a position to use confidential information it previously obtained from the subject company. As a policy natter, it can be argued that internal use of the information by a bank is improper since it gives the bank a competitive advantage by permitting it to base its lending determination on information which is generally not available to other banks. In addition, the information, in all likelihood, was provided to the bank by the subject company with a reasonable expectation that it would be kept confidential and, in any event, that it would not be used contrary to the interests of the subject company or its management. Thus, the bank's use of the information could result in a breach of a common law fiduciary obligation owed by the bank to the subject company.

SEC Memoranduin 6 (footnotes omitted).

49. Letter from Senators Proxmire, Sarbanes, and Williams to Harold M. Williams, Chairman, Securities and Exchange Commission (July 3, 1979), reprinted in [1980] SEC. REG. \& L. REP. (BNA) No. 542 at A-3 (Special Supplement).

50. Id. 
formation in [tender offers], where there is such a close relationship between the conduct of banks and securities transactions." 51 In the memorandum accoinpanying the Williams letter, the Commission suggested that a bank that uses nonpublic information in deciding whether to finance a tender offer may violate section 14(e) of the 1934 Act, ${ }^{52}$ even if it does not violate rule 10b-5.53 Althougl the bank's internal use of information would not satisfy the "in connection with the purcliase or sale of any security" requirement of rule $10 \mathrm{~b}-5,{ }^{54}$ the decision to finance a takeover might be "in connection with" a tender offer, and thus fall under the antifraud provisions of section 14(e). The prospective offeror, in contrast, would not be liable for the bank's strictly internal use of confidential information. ${ }^{55}$ The Commission went on to make legislative proposals to deal with the use of material nonpublic information by banks. ${ }^{56}$

Section 13(d)(1)(B) of the 1934 Act $^{57}$ currently requires disclosure of the name of the bank financing the offeror only if the loan is not made in the ordinary course of the bank's business. The Securities and Excliange Commission lias stated that the purpose of the existimg provision is to prevent "a subject company from exertimg pressure on the bank to withhold financing for a tender offer." 58 The Commission's proposed amendment to section 13(d)(1)(B) would require tender offerors to disclose the name of any bank that lends funds to finance a tender offer if the bank has had a commercial relationship with the target company within the past two years. ${ }^{59}$ The Commission mdicated

51. Letter from Harold M. Williams to Senator Proxmire (February 15, 1980), reprinted in [1980] SEC. REg. \& L. REP. (BNA) No. 542 at A-3 (Special Supplement).

52. 15 U.S.C. $\$ 78 n(e)$. See note 33 supra.

53. SEC Memorandum 7.

54. See 17 C.F.R. § 240.10b-5 (1980).

55. SEC Memorandum 7.

56. See SEC Memorandum 10 for the legislative proposal to prohibit a bank that finances a tender offer from disclosing material nonpubhic imformation obtained from the target company. See note 33 supra.

57. 15 U.S.C. $\$ 78 \mathrm{~m}$ (d)(1)(B) (1976).

58. SEC Memorandum 9.

59. The Commission's explanation was as follows:

[T]he Commission recommends that Section $13(\mathrm{~d})(1)(B)$ be amended to require the bidder to disclose the name of the lender financing a tender offer or acquisition except where a source of funds is a loan made in the ordmary course of business by a bank and no prior or present commercial relationship exists between such bank and the subject company. As amended, Section $13(d)(1)(B)$ would require that a bidder disclose: the source and amount of the funds or other consideration used or to be used in making the purchases, and if any part of the purchase price or proposed purchase price is represented or is to be represented by funds or other consideration borrowed or otherwise obtained for the purpose of acquiring, holding, or trading such security, a description of the transaction and the names of the parties thereto, except that where a source of funds is a loan made in the ordinary course of business by a bank, as defined in Section $3(a)(6)$ of this title, and, after reasonable inquiry, the person 
that if this proposal is adopted, it will consider amending schedule $14 \mathrm{D}-1^{60}$ to require additional disclosure of the nature and extent of the commercial relationship between the bank and the target company.

The proposed revisions of section 13(d)(1)(B) and schedule 14D-1 are intended to discourage the financing of a tender offer by a bank having a commercial relationship with the target company. Requiring disclosure of the identity of the bank, thus subjecting it to pressure and possibly to lawsuits, would deter a bank from lending funds to a company that intends to acquire a customer or former customer. Hence, the Commission's proposal represents a reversal of the former policy of not hampering bank financing of tender offers. ${ }^{61}$

Until the Security and Exchange Commission's initiative is adopted or rejected, however, banks should carefully consider what policies they should follow regarding the financing of tender offers when the target company is a present or past customer. Two commentators have proposed that a bank disclose in its advertising and promotional literature that its policies do not preclude the financing of takeovers of its customers, and that in evaluating a loan apphication it will consider all information in its possession. ${ }^{62}$ This proposal has two obvious drawbacks: it will drive away customers, and it will probably not accomplish its purpose of imphicitly waiving the bank's fiduciary duty not to misuse nonpublic information.

Even if this proposal could msulate a bank from its fiduciary responsibility to its customer, it would lave no bearmg on the Commission's legislative recommendation. The Commission's proposal aims at

\footnotetext{
filing the statement does not know or have reason to know that any prior or present commercial relationship exists between such bank and the issuer of the class of securities to be acquired, the name of the bank shall not be made available to the public, if the person filing such statement so requests.
}

SEC Memorandum 10. The Commission suggested that a "prior commercial relationship" could be defined as a busmess relationship between a bank and a subject company that existed within two years prior to the date that the bidder first approached the bank. Id. The Commission considered and rejected two other proposals. The first would have required the disclosure of the name of the bank if the bank was in possession of material nonpubic information obtained from the target company. The second would have required disclosure of the bank's name in all cases. Id. $9-10$.

60. Scliedule 14D-1, 17 C.F.R. $\$ 240.14 d-100$ (1980), is the disclosure statement that an offeror must file on the date of the commencement of its tender offer. The schedule is also used in certain situations to satisfy the reporting requirements under section 13(d) of the 1934 Act, 15 U.S.C. $\$ 78 \mathrm{~m}(1976)$.

61. See text accompanying note 58 supra. Cf. Letter from Paul A. Volcker, Chairman of the Board of Governors of the Federal Reserve System, to all member banks (Oct. 23, 1979) (advising the banks that, in allocating available credit, they should avoid making loans for "extraordinary financial transactions," such as loans for corporate takeovers). (1979).

62. Herzel \& Rosenberg, Bank Financing of Tender Offers, 12 Rev. SEc. ReG. 892, 894 
disclosure of conflicts of interest by banks in particular transactions for the benefit of target coinpany shareholders. Disclosure of potential conflicts to corporate customers would not accomplisl this goal. Hence, in light of the confusion in the case law and the position the Commission has recently taken on this issue, the only clear way a bank can avoid hability is to decline to finance acquisitions of target companies about which the bank possesses material nonpublic information.

\section{Disclosure of Nonpublic Information by a Bank's Commercial Department to its Trust Department.}

With the growth of trust departments in large commercial banks, the traditional separation between the institutional lender and the institutional fiduciary has alinost disappeared. In 1970 commercial banks managed $\$ 292$ billion as fiduciaries, ${ }^{63}$ equal to nearly two-thirds of the commercial banking assets held by the same banks. The trust departnient is often a bank's largest depositor. ${ }^{64}$ In the past decade there has been an increased recognition that the operation of trust and commercial departments by a simgle bank requires the bank to perform duties that may conflict, chiefly with respect to the management and use of material nonpublic information.

1. The Trustee's Duty of Undivided Loyalty, Care, and Skill. A trustee owes a fundamental common law duty to its beneficiary to admimister the trust solely in the interest of the beneficiary ${ }^{65}$ and with an ordmary degree of care, skill, and prudence. 66 Federal law has recognized this duty in section 404 of the Employee Retirement Income Security Act of 197467 (ERISA), which governs the duties of trustees of employee benefit plans.

63. Ehrlich, The Functions and Investment Policies of Personal Trust Departments, 1972 Monthly Rev. Fed. RES. BANK N.Y. 255.

64. Hunsicker, Conficts of Interest, Economic Distortions and the Separation of Trust and Commercial Banking Functions, 50 S. CAL. L. REv. 611, 622 (1977). Most trust department deposits are of uninvested funds held in demand accounts. Id.

65. See RESTATEMENT (SECOND) OF TRUSTS $\$ 170(1)$ (1959); $c f$ Albright v. Jefferson County Nat'l Bank, 292 N.Y. 31, 53 N.E.2d 753 (1944) (a corporate trustee is prohibited from placing itself in a position where its own interests may conflict with its duties as a trustee).

66. See RESTATEMENT (SECOND) OF TRUSTS $\$$ 174, 227(a) (1959).

67. 29 U.S.C. $\$ 1104$ (1976). Section 404 provides that a fiduciary:

shall discharge his duties with respect to a plan solely in the interest of the participants and beneficiaries and-

(A) for the exclusive purpose of:

(i) providing benefits to participants and their beneficiaries; and

(ii) defraying reasonable expenses of administering the plan;

(B) with the care, skill, prudence, and diligence under the circumstances then prevailing that a prudent man acting in a like capacity and familiar witl sueh 
Institutional trustees must meet a higher standard of professional skill and care than individual trustees. ${ }^{68}$ Individual trustees generally inust investigate the safety of and probable income from prospective investments, and inust secure information about such investments from custoinary sources. The trust department of a bank, however, must investigate investments more thoroughly than an individual trustee, using all the facilities at its disposal. ${ }^{69}$

To satisfy these standards, the past practice of trust departinents was to make mvestment decisions based on all available information, including inaterial nonpublic information obtained from the bank's commercial customers. Soliciting and acquiring inaterial nonpublic information was considered to be evidence of the care and prudence of the trustees. Banks developed lines of communication between their commercial and trust departunents to discharge fully this duty they perceived as salutary. ${ }^{70}$ Banks have recently been inade aware, however, that the smgle-minded prounotion of the interests of trust beneficiaries inay expose them to liability to commercial departunent custonners under cominon law principles, and to purchasers and sellers of securities under the federal securities laws.

2. The Bank's Duty of Confidentiality Under Common Law. A bank has a duty under common law to unaintain in confidence nonpub-

Inatters would use in the conduct of an enterprise of a like character and with like aims .... .

The Conference Report on this section states: "Under the conference substitute each fiduciary of a plan must act solely in the interests of the plan's participants and beneficiaries and exclusively to provide benefits to these participants and beneficiaries (or to pay reasonable plan administrative costs)." H.R. REP. No. 93-1280, 93d Cong., 2d Sess. 243, 303 (1974) (Joint Explanatory Statement of the Committee of Conference), reprinted in [1974] U.S. CODE CONG. \& AD. NEwS 5038, 5083.

Tlie "prudent man" standard incorporated in ERISA is derived from section 174 of the RESTATEMENT (SECOND) OF TRUSTS, which states: "The trustee is under a duty to the beneficiary in administering the trust to exercise such care and skill as a man of ordinary prudence would exercise in dealing with his own property...."

68. See Restatement (Second) of Trusts $\$ 227$, Comment d (1959).

69. Id. The standard for trustees generally is as follows:

The trustee does not use due care in making an investment unless he makes an investigation as to the safety of the imvestment and the probable imcome to be derived therefrom. Ordmarily this imvolves securing imformation from sources on which prudent men im the community customarily rely. He may take into consideration advice given to him by attorneys, bankers, brokers and others whom prudent men in the community regard as qualified to give advice, but he is not ordmarily justified in relying solely on such advice, but must exercise his own judgnent.

Id., Comment b. Comment $\mathrm{d}$ states the inore stringent requirement for the corporate trustee: If the trustee is a bank or trust company, it must use in selecting investments the facilities which it has or should have, and it may properly be required to show that it has made a more thorough and coinplete investigation than would ordinarily be expected from an individual trustee.

Id., Comment d.

70. See Hunsicker, supra note 64, at 631-32. 
lic information obtained froin commercial department customers. This duty was discussed previously in the context of financing takeovers of a custoiner of the bank..$^{71}$ The stateinents of the duty $\mathrm{m}$ that context, however, are broad enough to embrace a similar duty of the commercial department not to pass material nonpublic information to the trust department. ${ }^{72}$ Although no cases apply this rule of confidentiality to trading by a bank's trust departinent, the court of appeals' decision in Schein $\nu$. Chasen ${ }^{73}$ presents an analogous situation. In that case a corporate officer tipped an einployee of Lehman Brothers that the corporation would not achieve the earnings previously projected. The Lehman Brothers employee passed this information on to some of his institutional custoiners, who sold large blocks of the corporation's stock before the revised earnings projections were publicly disclosed.

In a shareholders' derivative action, the Court of Appeals for the Second Circuit held that the corporation had a common law cause of action against both the corporate officer and the tippees for the profits the tippees derived froin using the information. The court ruled that the duty of confidentiality falls not only on "technical fiduciaries," but also on those who becoine fiduciaries by acquiring confidential information froin a fiduciary. ${ }^{74}$ The tippees were thus "automatically clothed with a duty to [the corporation] not to use the information for their own selfish advantages."75 Hence, the Schein decision suggests that liability unay be imposed on a bank whose trust department trades on confidential information obtamed from a customer by the commercial department.

\section{The Bank's Duty of Confidentiality under the Federal Securities} Laws. A bank possessing material nonpublic information about a publicly lield commercial department customer may have a responsibihty

71. See text accompanying notes 17-39 supra.

72. While the link between the use of nonpublic information and the harm to the commercial department customer in the context of ordinary market transactions by the trust department may not be as clear as in acquisition situations, there are nonetheless certain instances in which the harm can be great. For example, trading on adverse nonpublic information by a bank trust department could result in a severe decline in the price of a company's stock before the company has had an opportunity to make an orderly and complete disclosure of the adverse development.

In Thomas v. Roblim lndus., 520 F.2d 1393 (3d Cir. 1975), the court stated that as a matter of common law, a fiduciary of a corporation who trades for his own benefit on the basis of nonpublic information breaches a duty to the corporation regardless of whether the corporation suffers damage as a result of his trading. Id. at 1397; see Diamond v. Oreainuno, 24 N.Y.2d 494, 248 N.E.2d 910 (1969) (enunciating the saine rule under New York Law).

73. 478 F.2d 817 (2d Cir. 1973), vacated on other grounds sub nom. Lehman Bros. v. Schein, 416 U.S. 386 (1974).

74. 478 F.2d at 823 .

75. Id. 
under the federal securities laws to prevent its trust department from trading on the basis of such information. Before the Supreme Court's recent decision in Chiarella $v$. United States, ${ }^{76}$ one who traded on material nonpublic information without disclosure clearly violated rule $10 \mathrm{~b}$ 5 and was liable to defrauded purchasers or sellers. ${ }^{77}$ The rule applied both to corporate insiders ${ }^{78}$ and to their tippees. ${ }^{79}$ This rule, sometimes referred to as the "disclose or abstain from trading" rule, was most clearly stated by the Court of Appeals for the Second Circuit in $S E C \nu$. Texas Gulf Sulphur C0. ${ }^{80}$ The court in Texas Gulf Sulphur held that insiders witl access to information that is intended for a corporate purpose inay not publicly trade on it knowing that the public lacks access to the inside information. ${ }^{81}$ But the court then stated that

the Rule is also applicable to one possessing the information who may not be strictly termed an "insider" within the meaning of Sec. 16(b) of the Act. . . . Thus, anyone in possession of material inside information must either disclose it to the investing public, or, if he is disabled froin disclosing it in order to protect a corporate confidence, or he chooses not to do so, inust abstain from trading in or recommending the securities concerned while such inside information remams undisclosed. ${ }^{82}$

The Texas Gulf Sulphur decision suggested that anyone who trades on material nonpublic information without disclosure violates rule $10 \mathrm{~b}-5$.

The Second Circuit narrowed this suggestion in SEC v. Monarch Fund. ${ }^{83}$ In that case, two investınent partnerships traded on nonpublic information that a company was about to complete a major private placement of its convertible debentures. The partnerships' advisor had learned of the private placement "from several sources" and had veri-

76. 445 U.S. 222 (1980).

77. See, e.g., Shapiro v. Merrill Lynch, Pierce, Fenner \& Smith, lnc., 495 F.2d 228 (2d Cir. 1974); SEC v. Shapiro, 494 F.2d 1301 (2d Cir. 1974); SEC v. Texas Gulf Sulphur Co., 401 F.2d 833 (2d Cir. 1968) (en banc), cert. denied, 394 U.S. 976 (1969) and 404 U.S. 1005 (1971); SEC v. Lum's, Inc., 365 F. Supp. 1046 (S.D.N.Y. 1973). See also Investors Management Co., Sec. Exchange Act Release No. 9267, [1970-1971 Transfer Bimder] FED. SEC. L. REP. (CCH) đ 78,163 (1971); Merrill Lynch, Pierce, Fenner \& Smith, Inc., Sec. Exchange Act Release No. 8459, [19671969 Transfer Binder] Fed. SEC. L. Rep. (CCH) If 77,629 (1968); Cady, Roberts \& Co., Sec. Exchange Act Release No. 6668, [1961-1964 Transfer Binder] Fed. SEc. L. ReP. (CCH) I 76,803 (196I).

78. See, e.g., Cady, Roberts \& Co., Sec. Exchange Act Release No. 6668, [1961-1964 Transfer Binder] FED. SEC. L. REP. (CCH) \ 76,803 (1961).

79. See, e.g., SEC v. Lum's, Inc., 365 F. Supp. 1046 (S.D.N.Y. 1973).

80. 401 F.2d 833 (2d Cir. 1968) (en banc), cert. denied, 394 U.S. 976 (1969) and 404 U.S. 1005 (1971).

81. 401 F.2d at 848 .

82. $I d$.

83. 608 F.2d 938 (2d Cir. 1979). 
fied it in a conversation with a director of the company. ${ }^{84}$ The district court held that the defendants violated rule 10b-5 because the partnerships had traded on information that the advisor knew or had reason to know was not public and that had been obtained "improperly by selective revelation or otherwise." 85

The court of appeals reversed. ${ }^{86}$ lt distinguished true insiders, sucli as officers, directors, and employees of a company, from outsiders who inay have obtained nonpublic information. ${ }^{87}$ The court stated that insiders have a degree of knowledge that makes them culpable if they trade on nonpublic information. ${ }^{88}$ The court was unwilling to make this assumption for outsiders, choosing instead to determine their culpability by whether they had reason to know they were trading on nonpublic information. ${ }^{89}$ The court found that the Monarch Fund defendants were not liable, because the record did not indicate whether the advisor had reason to know that his contacts acted improperly in giving him information about the private placement.90

In Chiarella v. United States ${ }^{91}$ the Supreme Court specifically repudiated the broad rule suggested by Texas Gulf Sulphur. The Court held that rule 10b-5's prohibition against trading on nonpublic information extends only to "traditional corporate insiders"-directors, officers, and controlling shareholders-and to those who owe a duty to disclose such mformation to the prospective seller or purchaser of the securities. ${ }^{92}$

Although Chiarella clearly limits the scope of $10 \mathrm{~b}-5$ liability for trading on nonpublic information, ${ }^{93}$ the implications of that decision

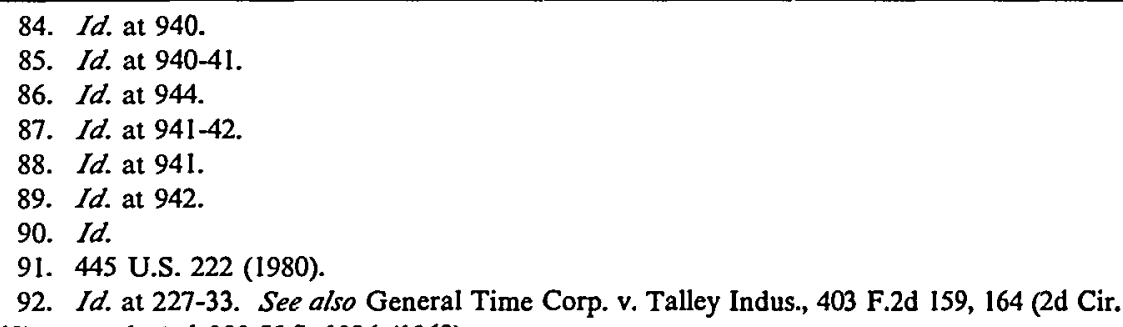
1968), cert. denied, 393 U.S. 1026 (1969).

93. The Securities and Exchange Commission contends that the scope of the holding in Chiarella is not so clear. In its release accompanying the promulgation of rule 14e-3, 45 Fed. Reg. 60,410 (1980), the Commission states that the Supreme Court did not decide whether a person violates rule $10 \mathrm{~b}-5$ by trading while in possession of material nonpublic information obtained by unlawful means. Id. 60,411. As an alternate theory of liability, the Commission had argued in Chiarella that such trading violated rule 10b-5. The Supreme Cour, however, refused to consider this theory because it had not been submitted to the jury in the district court. 445 U.S. at 236 . Hence, the Commission noted in its release that "im view of the hinited holding in Chiarella, the Commission continues to believe" that tradimg while in possession of material nonpublic informa. tion "misappropriated or obtained or used by unlawful ineans" violates rule 10b-5. 45 Fed. Reg. at $60,412 \& \mathrm{n} .20$. 
for a trust department's securities transactions are unclear. After Chiarella there remaim three theories on which a bank whose trust department trades on nonpublic information may be liable under rule 10b-5: first, the bank's receipt of nonpublic information as a tippeefor example, as a result of a breach of fiduciary duty by a traditional corporate insider such as an executive officer, a director, or a principal shareholder; ${ }^{44}$ second, the bank's status as a corporate insider; 95 and third, the bank's fiduciary duty to a particular person or class of persons witll whom it traded.96

It is conceivable, however, that under Chiarella a bank's trust department could trade on material nonpublic information that it received in the ordinary course of a commercial lending relationship without violating rule $10 \mathrm{~b}-5$. In that situation, the bank would not be a tippee, for it would have obtained the nonpublic information lawfully and not by virtue of a corporate imsider's breach of fiduciary duty. If a bank does not become an insider by reason of its lending relationship with a company, the only way a bank could incur rule 10b-5 hability under the Chiarella analysis is if some other basis exists to establish a fiduciary relationship between the bank and the borrower's shareholders. ${ }^{97}$

While it is correct that the Court in Chiarella did not rule on the alternate theory put forth by the Cornmission, it is somewhat misleading to suggest that the Court's decision did not cast serious doubt on this theory. In Chiarella the Court focused on the absence of a relationship between the parties to the transaction and rejected several theories that would have found the defendant hable because he traded on the material nonpublic information. The Commission's alternate theory looks to how the information was obtamed rather than the identity of the user. This theory is much closer to the arguments that the Supreme Court rejected than it is to the theory of habihty under rule 10b-5 that the Supreme Court adopted.

The Coinmission also states that, in its view, the decision in Chiarella did not suggest any limitation on its authority under section 14(e) of the 1934 Act to adopt a rule regarding trading while in possession of material nonpublic information relating to a tender offer. Id. $60,4 \mathrm{Il}$. See note 38 supra for a discussion of the authority of the Commission to adopt rule 14e-3.

94. When a bank receives nonpublic information in the normal course of a commercial lending relationship, the disclosure of such information to the bank would not, absent extraordinary circumstances, be in breach of the insider's fiduciary duty to his corporation, and thus a bank should not incur tippee liability.

95. See text accompanying notes 31-32 supra.

96. This duty could result from soine special relationship of the bank to the other party to a transaction. For example, if the bank or one of its affiliates bought or sold securities from an individual for whoin the bank was acting as trustee, the bank would almost certainly have a fiduciary duty to disclose.

97. The Court in Chiarella took note of the fact that the nonpublic information obtained by the defendant was "market information," which "did not concern the earning power or operations of the target coinpany, but only the plans of the acquiring company." 445 U.S. at 231. Moreover, the sources of this information were not the target compamies, but the coinpamies about to make tender offers. Although the holding in Chiarella is not limited to cases involving market imformation, lower courts seeking to restrict the case might apply it only to markct information. In addi- 
Affiliated Ute Citizens v. United States, ${ }^{98}$ which the Chiarella Court discussed at length, may shed some light on the Supreme Court's thinking on this question. In Affliated Ute Citizens a group of American Indians formed a corporation to manage tribal assets. ${ }^{99}$ The corporation appointed a bank as its transfer agent ${ }^{100}$ and imstructed it to discourage sales of the company's stock because of the difficulty of valuimg the sliares. ${ }^{101}$ Two bank employees helped the shareholders sell their stock. ${ }^{102}$ Later, these shareholders sued, claiming that the bank employees and the bank violated rule $10 \mathrm{~b}-5^{103}$ when the employees failed to inform the selling shareholders of material information relating to the value of their shares. ${ }^{104}$

The Supreme Court recognized that the bank would have had no duty of disclosure if it had been merely a transfer agent. ${ }^{105}$ The Court indicated in Chiarella, lowever, that it had found the bank liable in Affiliated Ute Citizens because, by agreeing to discourage sales of the company's stock, the bank "also had assuined a duty to act on behalf of the sliareliolders, and the Indian sellers had relied upon its personnel when they sold their stock."106

One might conclude that by relying on Affiliated Ute Citizens, the Court in Chiarella intended to limit the fiduciary duties that require disclosure under rule $10 \mathrm{~b}-5$ to those duties specifically assumed in connection with purchases or sales of securities. ${ }^{107}$ If this conclusion is

tion, subsequent cases may create additional duties of disclosure based on relationships not explored in the Chiarella opinion.

In Walton v. Morgan Stanley \& Co., 623 F.2d 796 (2d Cir. 1980), decided soon after the Chiarella decision, the Court of Appeals for the Second Circuit held that the securities firm of Morgan Stanley \& Co. did not become a fiduciary of Olinkraft Corporation merely because Olinkraft, which was the subject of a possible acquisition, provided Morgan Stanley with confidential information while Morgan Stanley was acting as an advisor to another corporation that was looking for acquisition possibilities.

98. 406 U.S. I28 (1972).

99. Id. at 136.

100. Id. at 136-37.

101. Id. at 146 .

102. Id.

103. Id. at 140.

104. The plaintiffs joined the United States as a defendant, alleging that the United States had a duty to prevent the sale of the stock under fraudulent circumstances and therefore was liable under the Federal Tort Claims Act, 28 U.S.C. $\$ \S 2671-2680$ (1976). 406 U.S. at 140.

105. 406 U.S. at 151-52.

106. 445 U.S. at 230.

107. The Securities and Exchange Commission, in its release accompanying the adoption of rule 14e-3, reached a similar conclusion regarding the meaning of the Supreme Court's reliance on Affiliated Ute Citizens:

The Court also affirmed its holding in Affiliated Ute Citizens v. United States that a fiduciary may not trade with its beneficiary while in possession of material information of which the beneficiary is not aware. Thus, persons who possess such information and 
correct, the vast majority of securities transactions that bank trust departments engage im are exempt from liability under rule $10 \mathrm{~b}-5$ for nondisclosure, because banks rarely assume the kinds of duties that would trigger the duty to disclose.

The Securities and Exchange Commission has attempted to avoid the implications of Chiarella for tender offer trading by adopting rule 14e-3(a). ${ }^{108}$ The purpose of the rule is to create a duty of disclosure under section 14(e) of the 1934 Act whether or not there is any fiduciary relationship between the purchaser and seller of securities. Hence, had the Court decided Chiarella under rule 14e-3(a), rather than rule $10 \mathrm{~b}-5$, the defendant's trading would have violated the securities laws.

Were it not for an exception, rule $14 \mathrm{e}-3$ (a) would have a harmful effect on banks and other financial institutions. For example, if a tender offeror persuades the commercial department of a bank to finance a tender offer and gives the bank material nonpublic information about the offer, the bank violates the rule if its trust department innocently purchases or sells securities of the target company before the information is made public. To avoid this result, rule $14 \mathrm{e}-3(\mathrm{~b})$ was added as an exception to rule $14 \mathrm{e}-3(\mathrm{a}) .{ }^{109}$ The exception exempts an insti-

\footnotetext{
in whom a purchaser or seller has reasonably reposed trust and confidence with respect to securities transactions are subject to a duty to disclose that information or to abstain from trading with such purchaser or seller.
}

45 Fed. Reg. at 60,412 (footnotes and citations omitted).

108. See notes 34-35 supra. The rule prohibits trading without disclosure in securities that are the subject of a tender offer by a person, other than the offeror, who has information about the offer that he knows or has reason to know is nonpublic and has been acquired directly or indirectly froin the offeror, the target, or any officer, director, partner, employee, or advisor of either.

The rule applies whenever either a tender offer has commenced or a substantial step has been taken to commence a tender offer. The Commission states that this standard "is not totally objective." 45 Fed. Reg. at 60,413 n.33. In the release accoinpanying the adoption of the rule, the Commission gives the following examples of substantial steps to commence a tender offer: voting on a resolution by the offeror's board relating to the offer; formulating a plan to make a tender offer; arranging financing; preparing or authorizing tender offer inaterials; and obtaining a soliciting dealer, forwarding agent, or depository. Id. All of these examples involve acts which are unlikely to be known by outsiders, and it is not required that a person actually know that a substantial step to commence a tender offer has been taken for him to violate the rule. Thus, rule 14e-3(a) undoubtedly will prevent trading without disclosure any time a person subject to the rule has inaterial nonpublic information about a tender offer that he has reason to believe einanated froin one of the sources listed in the rule.

Purchases of a security which is the subject of the offer by a broker or other agent on behalf of the offering person, and sales of such a security to the offering person, do not violate the rule. Rule 14e-3(c), 45 Fed. Reg. 60,418 (1980) (to be codified in 17 C.F.R. $\$ 240.14$ e-3(c)).

109. Rule 14e-3(b) states:

(b) A person other than a natural person shall not violate paragraph (a) of this section if such person shows that:

(1) The individual(s) inaking the investment decision on behalf of such person to purchase or sell any security described in paragraph (a) of this section or to cause any such security to be purchased or sold by or on behalf of others did not know the material, nonpubhic information; and 
tution from liability under rule $14 \mathrm{e}-3(\mathrm{a})$ if it can meet two requirements. First, the institution must prove that the persons who bouglit or sold the securities for the institution did not know the nonpublic information when they made the mvestment decision. Second, the institution must show that it has adopted reasonable procedures to prevent the violation of the first requirement. ${ }^{110}$ The procedures "may include, but are not limited to" lists that restrict the purchase or sale of the security (restricted lists) or methods that prevent the imvestment decision-maker from knowing the nonpublic mformation (Chinese Walls). ${ }^{111}$

The adoption of rule 14e- 3 creates an anomaly under the federal securities laws. Section 14(e) of the 1934 Act, the antifraud provision that specifically applies to tender offers, now incorporates a "disclose or abstam from trading" rule. Section $10(\mathrm{~b})$ of the Act and rule 10b-5, the antifraud provisions of the 1934 Act that apply generally to purchases and sales of securities, require disclosure only when the relationship between parties to the transaction creates an obhigation to disclose. ${ }^{112}$ Hence, the Securities and Exchange Commission has imposed a more stringent rule on tender offer trading than exists for securities trading generally.

4. Attempted Reconciliation of a Bank's Conflicting Duties. As discussed above, banks may find that their duties to trust departınent customers conflict with their obligations under common law and federal securities law not to use nonpublic information. Some authorities have attempted to resolve these conflicts through the traditional trust law doctrine that a trustee may not commit acts in furtherance of the trust

(2) Such person had implemented one or a combination of policies and procedures, reasonable under the circumstances, taking into consideration the nature of the person's business, to ensure that individual(s) making investment decision(s) would not violate paragraph (a) of this section, which policies and procedures may include, but are not limited to, (i) those which restrict any purchase, sale and causing [sic] any purchase and sale of any such security or (ii) those which prevent such individual(s) from knowing such information.

45 Fed. Reg. 60,418 (1980) (to be codified in 17 C.F.R. $\$ 240.14 e-3(b)$ ).

110. The institution has the burden of proof for beth elements of the exception. 45 Fed. Reg. at 60,415 . In the release accompanying the adoption of rule $14 \mathrm{e}-3$, the Commission states that a person attempting to establish the "non-availability" of the exception in rule 14e-3(b) "may be able after the imstitution has met the initial burden to show circumstances under which it would not be reasonable that the individual decision maker(s) did not know the information." Id. 60,415 n.43. The Commission then states that this evidence may also bear on the effectiveness of the policies and procedures in the second element of the exception. Id. Of course, the Commission misspoke when it referred to a person attempting to establish the non-availabihty of the exception, because the institution has the burden of proving that the exception is available to it. Id. 60,415 .

111. The procedures adopted inust be "reasonable under the circumstances." Id.

112. See Koeltl \& Kubek, supra note 38, at 906. 
that are illegal or against public policy. ${ }^{113}$ These authorities argue that a bank that does not use nonpublic information because of potential liability under common law or federal securities laws should not incur liability to its trust department customers for a breach of the bank's duty of care and skill. ${ }^{114}$

This argument forms the basis of the "Chinese Wall" concept. Yet there are at least two reasons to doubt the soundness of the argument. First, there are certain uses of nonpublic information on behalf of trust beneficiaries for which a bank is not liable under either the federal securities laws or common law. For example, the use of nonpublic inforination in a decision not to sell or not to buy a security does not violate the federal antifraud provisions. Only decisions im connection with the purchase or sale of a security violate these provisions. ${ }^{115}$ Furthermore, while there appear to be no decisions on point, it is almost certain that no common law duty is violated by such use of nonpublic information. The reasons given by the Supreme Court for limitimg federal antifraud damage actions to purchasers or sellers of securities would also apply to common law actions. In Blue Chip Stamps v. Manor Drug Stores ${ }^{116}$ the Supreme Court retained the limitation because of a fear that to abolish it would stimulate a flood of baseless lawsuits. ${ }^{17}$ For similar reasons it is unlikely that any court would fashion a common law remedy for those who neither purchased nor sold securities but who merely allege

113. See, e.g., Commonwealth v. Brown, 260 F. Supp. 323 (E.D. Pa. 1966) (a trust held unenforceable as violative of statutes or public policy); Colonial Trust Co. v. Brown, 105 Conn. 261, 135 A. 555 (1926) (provisions of a trust held invalid on public policy grounds); Bauer v. Bates Lumber Co., 84 N.M. 391, 503 P.2d 1169 (Ct. App. 1972) (provisions of a trust held invalid because they violated a statute); ABA Committee Comment, Problems of Fiduciaries Under the Securities Laws, 9 REAL PROP., PROB. \& TR. J. 292, 303 (1974). For an example of an express statutory prohibition, see IND. CODE $\S 30-4-2-12$ (1971): "The terms of the trust may not require the trustee to commit a criminal or tortious act or an act which is contrary to public policy." See also Restatement (Second) of TRusts $\$ \S 62,166$ (1959); A. Scott, The Law of Trusts $\$ \$ 61,166$ (3d ed. 1967).

114. This position apparently derives from the RESTATEMENT (SECOND) OF TRUSTS $\$ 166$ (1959).

115. See Blue Chip Stamps v. Manor Drug Stores, 421 U.S. 723 (1975) (reaffirming the doctrine that to inamtain a private cause of action for dainages under rule $10 \mathrm{~b}-5$, the plaintiff inust have been a purcliaser or seller of securities). Similarly, a violation of the Commission's newly adopted rule 14e-3(a) occurs only if there has been a purchase or sale of a security. See 45 Fed. Reg. at 60,413 .

116. 421 U.S. 723 (1975).

117. The Blue Chip Stamps Court gave two reasons for retaining the purciraser-seller requirement under rule $10 \mathrm{~b}-5$. First, the requirement conveniently separates the plaintiff whose version of the facts is inore likely to be believed by the trier of fact because he actually purchased or sold securities, froin the much larger group of potential plaintiffs whose versions of the facts are inuch less likely to be believed because their only action was not to buy or sell. Id. at 743 . Second, to abolish the purchaser-seller requirement would require the trier of fact to decide many hazy issues of fact almost entirely on oral testimony. $I d$. 
that because of the defendant's fraud they did not buy or sell and thereby suffered damages.

A second reason for doubtimg the validity of the argument based on traditional trust law doctrine is that several cases have suggested that a fiduciary, faced with conflicting legal duties, cannot resolve the conflict by clroosing between them to the disadvantage of one of the parties to whom it owes a duty. In Black $v$. Shearson, Hammill \& Co. ${ }^{118}$ for example, a securities firm recommended the purchase of certam securities to its retail customers without divulging adverse nonpublic infornation $\mathrm{m}$ its possession. One of the members of the securities firm was also a director of the corporation that issued the securities. When the customers sued the firm for fraud, the firm defended by arguing that the firm member's connection with the corporation created a fiduciary obligation not to disclose the adverse information. ${ }^{119}$ The court rejected that defense, stating that a person may not evade one fiduciary duty by voluntarily assuming a conflicting duty. ${ }^{120}$ Rather than failing to perform one duty im order to fulfill the other, the court stated, the fiduciary should avoid taking on conflicting duties or should end one relationship when the conflict develops. ${ }^{121}$

In Slade v. Shearson, Hammill \& Co. ${ }^{122}$ the defendants made a similar argument. Retail customers of Shearson, Hammill alleged that the firm had violated the federal securities laws when its retail division recommended the purchase of a security while its corporate finance division had material, adverse, nonpublic inforination about the issuer. Shearson, Hammill argued that it was legally prohibited from disclosing such information to its retail customers until the information becaine public. The district court disposed of that contention by noting that the firm had voluntarily assumed the two conflicting duties, neither of which had priority over the other. If fulfilling both duties produced a commercial loss, the loss was Shearson, Hammill's to bear. ${ }^{123}$

118. 266 Cal. App. 2d 362, 72 Cal. Rptr. 157 (1968).

119. Id. at $367-68,72$ Cal. Rptr. at 161.

120. Id. at 368, 72 Cal. Rptr. at 161 .

121. Id.

122. [1973-1974 Transfer Binder] Fed. SEC. L. REP. (CCH) I 94,329 (S.D.N.Y.) (denial of motion for summary judgment), question certified, [1973-1974 Transfer Binder] FED. SEC. L. REP. (CCH) If 94,439 (S.D.N.Y. 1974), remanded as certification improvidently granted, 517 F.2d 398 (2d Cir. 1974), settled, [1978 Transfer Binder] FED. SEC. L. REP. (CCH) I 96,473 (S.D.N.Y.) (the court approved the private monetary settlement between shareholder plaintiffs and securities firm).

123. [1973-1974 Transfer Binder] FED. SEC. L. REP. (CCH) I 94,329. The subsequent history of the case, see note 122 supra, which involved certification of a question to the Court of Appeals for the Second Circuit, a remand by the Second Circuit to the district court, and, finally, a settlement of the case, has rendered doubtful the precedential value of the district court's decision. A similar issue was presented in Cady, Roberts \& Co., Sec. Exchange Act Release No. 6668, [1961- 
The principle that a person who serves two interests in a fiduciary capacity cannot favor one over the other ${ }^{124}$ renders highly suspect the claim that the Chinese Wall reconciles the bank's conflicting duties. Hence, despite the outpouring of commentary on the Chinese Wall as a resolution of the conflict problems of banks and securities firms, ${ }^{125}$ the efficacy of the wall for that purpose is far from clear. ${ }^{126}$

\section{Is the Chinese Wall a Solution?}

The Chinese Wall concept originated in the settlement of a Securities and Exchange Commission proceeding against Merrill Lynch. ${ }^{127}$ Merrill Lynch had been the inanaging underwriter of an offering of Douglas Aircraft securities. Douglas Aircraft confidentially informed Merrill Lynch that it anticipated a drop im earnings. Brokers at Merrill

1964 Transfer Binder] FED. SEC. L. REP. (CCH) I 76,803. A party to the proceeding, Gintel, contended that the Securities and Exchange Commission should not discipline him for unaking sales from his customers' discretionary accounts based on material nonpublic information that was adverse to the issuer. Gintel claimed he owed a fiduciary duty to his customers that required him to sell the issuer's shares after he learned of the adverse information. The Commission rejected this position on the ground that the duty not to trade on inside information is primary. The Commission disagreed with Gintel's argument that the Commission's decision in Val Alstyne, Noel \& Co., 33 S.E.C. 311 (1952), supported Gintel's position. In that proceeding, a broker-dealer who sold securities to customers without revealing material adverse information in its possession about the issuer, contended that it received the adverse information in confidence and therefore could not disclose it. The Commission rejected the defense and found that the broker-dealer had violated the federal antifraud provisions.

124. See Local 734 v. Continental Ill. Nat'l Bank \& Trust Co., [1973-1974 Transfer Binder] FED. SEC. L. REP. (CCH) I 94,565 (N.D. Ill. 1974), vacated on rehearing sub nom. O'Brien v. Continental Ill. Nat'l Bank \& Trust Co., 431 F. Supp. 292 (N.D. Ill. 1977), rev'd in part and affd in part, 593 F.2d 54 (7th Cir. 1979). The plaintiffs, who were beneficiaries of trusts for which the defendant bank was either trustee or agent, contended that the bank in its capacity as a commercial lender obtained "inside information" about certain corporations indicating that investunent in their securities was unwise. The plaintiffs claimed that the purchases and retention for the trusts of securities issued by these corporations breached the bank's fiduciary duty as trustee. Neither the district court nor the Court of Appeals for the Seventh Circuit dealt with the issue directly.

125. See, e.g., Herzel \& Colling, The Chinese Wall and Conflict of Interest in Banks, 34 Bus. LAw. 73 (1978); Huck, The Fatal Lure of the "Impermeable Chinese Wall," 94 BankING L. J. 100 (1977); Lipton \& Mazur, The Chinese Wall Solution to the Confict Problems of Securities Firms, 50 N.Y.U. L. REv. 459 (1975); Chazen, Reinforcing the Chinese Wall: A Response, 51 N.Y.U. L. REv. 552 (1976); Lipton \& Mazur, The Chinese Wall: A Reply to Chazen, 51 N.Y.U. L. Rev. 579 (1976); Mendez-Penate, supra note 18.

Certain law firms have contended that they could establish Chinese Walls to eliminate their own conflict situations. In every case in which this issue has been raised, the courts have ruled against the law firms. See Armstrong v. McAlpin, 606 F.2d 28 (2d Cir. 1979); Westinghouse Elec. Corp. v. Kerr-McGee Corp., 580 F.2d 1311 (7th Cir.), cert. denied, 439 U.S. 955 (1978); Fund of Funds, Ltd. v. Arthur Andersen \& Co., 567 F.2d 225 (2d Cir. 1977).

126. "As a legal and practical matter the effectiveness of Chinese Walls in dealing with conflict situations is unclear." SEC Menorandun $8 \mathrm{n} .18$.

127. Merrill Lynch, Pierce, Feımer \& Smith, Inc., Sec. Exchange Act Release No. 8459, [19671969 Transfer Binder] FED. SEC. L. REP. (CCH) \ 77,629 (1968). 
Lynch then relayed the nonpublic information concerning the expected drop to selected customers who in turn traded on the private tip. The Securities and Exchange Commission proceeded against Merrill Lynch and certam of its employees for violating the securities laws.

In accepting Merrill Lynch's offer of settleinent, the Securities and Exchange Commission took special note of Merrill Lynch's plan to protect against the disclosure of confidential information in the future. The Commission singled out Merrill Lynch's new procedures for preventing dissemination of confidential information by the underwriting department to other branches of the firm. ${ }^{128}$ Although neither Merrill Lynch nor the Commission so named it, the practice of keeping confidential information within one division of a firm has come to be known as the Chinese Wall. ${ }^{29}$

Since the Merrill Lynch settlement in 1969 there has been surprisingly little mention of the Chinese Wall by courts or the Commission. Only the Court of Appeals for the Second Circuit, in Slade v. Shearson, Hammill \& Co., ${ }^{130}$ has explored the legal implications of the Chinese Wall in any depth. The Second Circuit did not take a position in the Chinese Wall debate; it remanded the case to the district court to develop a inore coinplete factual record. ${ }^{131}$ The court of appeals did, lowever, describe the positions of the parties and amici on the idea of the Chinese Wall. Shearson, Hammill argued that the federal securities laws precluded it from using inside information for the benefit of its customers. To prevent the passing of information froin one department to another, the brokerage firm therefore recommended placing a Chinese Wall between the retail and corporate finance departments. ${ }^{132}$ The plamtiffs, rather than challenging the concept of the Chinese Wall, attacked Shearson, Hammill's assertion that the securities laws prevent a broker from ending a selling campaign once it has received adverse inside information concerning the issuer. To view the prohibition on the use of inside information as requiring a broker to sell securities despite the possession of adverse infonnation would, the plaintiffs ar-

128. Id. at 83,350 . The term "Chinese Wall" is not used in the Merrill Lynch release. It is clear that the Securities and Exchange Commission did not give its unqualified approval to this procedure as a general cure-all. The Commission stated: "As a unatter of Commission policy, we do not, and indeed cannot, determine in advance that the Statement of Policy will prove adequate in all circumstances that may arise. Stringent measures will be required in order to avoid future violations." $I d$.

129. See, e.g., Lipton \& Mazur, The Chinese Wall Solution to the Conflict Problems of Securities Firms, 50 N.Y.U. L. REv. 459, 462 (1975).

130. 517 F.2d 398 (2d Cir. 1974).

131. Id. at 403 .

132. Id. at $402-03$. 
gued, turn the inside-information rule on its head and hicense a fraud on the public. ${ }^{133}$

The Securities and Exchange Commission, in its amicus brief, acknowledged both that inside information should not lead to market profit, and that brokers should deal fairly with their custoners. To harinonize these two primciples, the Commission advocated a reinforced Chinese Wall: a ban on transmission of mside information between departments, strengthened with a hist of companies whose securities the firm could not recommend because of an existing investment banking relationship. ${ }^{134}$ The amicus brief of the Salomon Brothers securities firm echoed the Commission's position on restricted hists. ${ }^{135}$ A second securities firm disagreed, however; Paine, Webber, Jackson \& Curtis, Inc. contended that the use of the wall reinforced with restricted lists conflicts with one of the key functions of an underwriter: to sponsor new securities issues in the inarket. ${ }^{136}$

This diversity of views demonstrates that even advocates of the Chinese Wall disagree about how to construct it. At least four variations have been suggested: the solid or impermeable wall, the permeable wall, the reinforced wall, and the administered wall.

The solid or impermeable wall ${ }^{137}$ consists of procedures to prevent the flow of nonpublic information from the bank's commercial department to its trust department. These procedures include: (1) circulating to commercial and trust department employees a statement that explains the firm's policies of prohibiting both the trading on nonpublic information and the communication of such information to the trust department, and that sets forth procedures for dealing with leaks; (2) instructing the bank's employees on the problein of insider trading; (3) restricting access to the commercial department's credit files by trust departınent einployees with investment responsibilities; (4) disclosing the existence of the wall to trust department customers; (5) prohibiting frequent transfers of einployees between the trust departinent and other departments; (6) forbidding trust departinent employees from sitting on committees that discuss credit matters; and (7) physically separating the trust departınent from the other departments of the bank. ${ }^{138}$

133. Id. at 403 .

134. Id.

135. Id.

136. Id.

137. A detailed description of an impermeable Chinese Wall for a bank can be found in Herzel \& Colling, supra note 125, at 88-91. See generally Chazen, supra note 125; Mendez-Penate, supra note 18.

138. Herzel \& Colling, supra note 125, at 88-91. 
The permeable Chinese Wall is less restrictive than the impermeable wall; it prevents the flow of material, rather than all, nonpublic information from the commercial to the trust department. ${ }^{139}$ Apparently, a bank desiring to establisl such a wall forms a screening mechanism that attempts to distinguish material from nonmaterial information. No attempt is made, however, to evaluate what uses of the information the trust department miglit properly inake.

The reinforced Chinese Wall concept derives from the Securities and Exchange Commission's and Salomon Brothers' proposals for securities firms in Slade v. Shearson, Hammill \& Co. ${ }^{140}$ The remforced wall consists of an impermeable wall fortified with a list of securities that the firm may not recommend to retail custonners. ${ }^{141}$ The list is coinposed of securities of compamies with which the securities firm has an investment banking relationship. Presumably, a restricted list for a bank trust department would mclude securities of companies with which the bank lias a commercial lending relationship. Instead of prohibiting the making of recommendations to buy or sell, a reinforced Chinese Wall for a bank would prohibit trading in securities on the restricted list.

Finally, the admmistered Chinese Wall is a permeable wall with formal procedures, imcluding the use of a committee of senior bank officers, established to control the fiow of information from the cominercial to the trust department. ${ }^{142}$ Rather than focusing on the elusive distinction between material and noninaterial information, as does the permeable wall, the administered wall determines how the bank should handle nonpublic information in its possession. It prevents the employees in the trust departnent from misusing material nonpublic information but makes this information available to the trust department for proper uses.

139. Mendez-Penate, supra note 18 , at 686 .

140. 517 F.2d 398 (2d Cir. 1974).

141. For a detailed diseussion of this proposal and a discussion of the various positions taken in the Slade case, see Lipton \& Mazur, The Chinese Wall Solution, supra note 125, at 482-90.

142. See Huck, supra note 125, at 114-23. An administered Chinese Wall makes a representative of the trust department responsible for providimg current lists of actual and prospective investments of the department to a representative of the commercial department. The commercial department then determines whether it possesses inaterial nonpublic information about any of the issuers of securities on the lists. If the cominercial department representative discovers any such information, he refers it to a committee of coinmercial and trust department officers that may halt trust department trading of securities about whicl the bank has material nonpublic information. The administered wall is, therefore, a flexible version of the reinforced wall. In effect, it uses nonpublic information in decisions not to purchase or sell by stopping all trading in securities about which the bank has material nonpublic information. 
The administered wall has several advantages over the other versions of the Chinese Wall. The impermeable wall inflexibly blocks all communication between the commercial and trust departinents. It therefore interferes with the trust department's fiduciary duty to use nonpublic information in deciding not to sell or not to buy a security for a trust beneficiary. ${ }^{143}$ The permeable wall is impractical because it permits trust officers to receive "nonmaterial" nonpublic information in the bank's possession. It places an enormous, perhaps impossible, burden on the bank officials to distinguish between what is and what is not material. ${ }^{144}$ The reinforced wall is an inflexible mechanisin that greatly reduces a trust departnient's investment options by restricting all trading in securities of issuers with which the bank has a commercial banking relationship. ${ }^{145}$

The admimistered wall, however, enables a group of experienced bank officers to review all the nonpublic information in the bank's possession and decide on an appropriate course of action, which might include an order not to sell or purchase particular securities. It has the advantage of restricting only those securities about which the bank possesses material nonpublic information.

For these reasons, of the various proposed forms of Chinese Walls, only the admimistered wall is an acceptable alternative for a bank. Prior to the adoption of rule $14 \mathrm{e}-3$ by the Securities and Exchange Commission, ${ }^{146}$ a bank could have dispensed with a Chinese Wall and simply prohibited all trading on the basis of nonpublic information obtained by any other department of the bank. Under such a system, an investinent committee of the trust departinent would identify information that falls within the prescribed category and decide, with the advice of counsel, whether knowledge of this information requires the bank to cease trading in a particular company's securities.

143. Herzel \& Colling, supra note 125 , at $85-86$. See note 124 supra for a discussion of Local 734 v.Continental 1ll. Nat'l Bank \& Trust Co., [1973-1974 Transfer Binder] FED. SEC. L. REP. (CCH) \94,565 (N.D. Ill. 1974), vacated on rehearing sub nom. O'Brien v. Continental Ill. Nat'l Bank \& Trust Co., 431 F. Supp. 292 (N.D. Ill. 1977), rev'd in part and aff'd in part, 593 F.2d 54 (7th Cir. 1979). Those who recommend an impermeable wall apparently believe that every use by the trust departinent of inaterial nonpublic information obtained from the commercial department violates the law. But no case has held that the use of nonpublic information in deciding not to sell or buy a security violates the antifraud provisions of the securities laws. Moreover, if Cliarella v. United States, 445 U.S. 222 (1980), is interpreted to permit a bank to trade on nonpublic information in certain circumstances, one of the principal justifications for the inpermeable wall would be seriously weakened.

144. See note 8 supra for discussion of the difficulty of distinguishing material information from nonmaterial information.

145. See Herzel \& Colling, supra note 125, at 82-83; Hunsicker, supra note 64, at 639-40.

146. See notes 33-39 supra and accompanying text. 
Although the Securities and Exchange Commission recently questioned the effectiveness of Chinese Walls in dealing with conflict situations, ${ }^{147}$ the Commission has virtually required banks to adopt Chinese Wall-type procedures to avoid liability under rule 14e-3.148 To qualify for the rule 14e-3(b) exeeption froin liability, an institution must show that it has adopted one or a combination of procedures to ensure that those making investment decisions for the institution do not violate rule 14e-3. Although the Commission emphasizes that it does not require any particular procedures, ${ }^{149}$ there are only two acceptable procedures specified in the rule: restricted hists and Chinese Walls. ${ }^{150}$ The release accompanying the adoption of rule $14 \mathrm{e}-3$ does not shed light on what other procedures, if any, may be acceptable. ${ }^{151}$

In light of the serious potential for liability under rule $14 \mathrm{e}-3$, the only prudent course of action for a bank is to adopt a restricted list or a Chinese Wall that satisfies rule $14 \mathrm{e}-3(\mathrm{~b}){ }^{152}$ Restricted list procedures, however, that prohibit trading in securities of issuers with which the

147. See note 126 supra.

148. See text accompanying notes 110-111 supra. In addition, the Comptroller of the Currency has promulgated a regulation requiring every national bank exercising fiduciary powers to adopt written policies and procedures to ensure that the federal securities laws are complied with in connection witl any decision or recoinmendation to purchase or sell a security. 12 C.F.R. $\S 9.7(d)(1980)$.

149. $45 \mathrm{Fed}$. Reg. at 60,416 . The Commission states that its position on procedures is consistent with that of the Federal Reserve Board and the Comptroller of the Currency. Id. 60,416 n.47. See note 148 supra for a discussion of the regulation issued by the Comptroller and note 152 infra for a discussion of the policy statement of the Board on the unisuse of nonpublic information. While the Comptroller took a truly neutral position on the procedures to be adopted by banks, the Federal Reserve Board strongly suggested the use of Chimese Walls.

150. 45 Fed. Reg. at 60,415 .

151. The release refers to "other infornal procedures that some institutions employ when they receive non-public information," mentioning specifically "watch lists," but later in the release a watch list is described merely as a procedure to monitor tradimg activity to determine whether there are any leaks in the Chinese Wall. $I d$.

152. There may be reasons other than rule $14 \mathrm{e}-3$ (b) for a bank to adopt a Chinese Wall. In a policy statement issued in 1978, the Federal Reserve Board stated that it will view the use of material inside information im connection with any decision or recommendation to purchase or sell securities as an unsafe and unsound banking practice. The Board stated that it expects each state member bank that exercises investment discretion for the accounts of others to adopt written policies and procedures, suitable to its particular circumstances, to cnsure that such information in its possession is not misused. The Board declined to mandate the specific content of policies and procedures to be adopted, but stated that in general they should limit those activities that are likely to give rise to an improper interchange of material imside information and should establish a course of action for the bank to deal with such infornation that may come into the possession of personnel engaged in investment decision-making for the accounts of others. The Board provided examples of what it referred to as "specific approaches to dealing with inside information that state member banks may wish to consider in the development of policies and procedures for their own use." These suggested approaches amount to the creation of a Chimese Wall. Federal Reserve System, Pohicy Statement Concerning Use of Inside Information, 43 Fed. Reg. 12,755, 12,756 (1978). See also INSTITUTIONAL INVESTOR STUdY Report, supra note 8, at 2539. 
bank has a lending relationship cannot be adopted, for they unduly narrow a bank's investment options. Thus, a bank trading in such securities would be forced to adopt some form of the Chinese Wall.

Even if a bank establishes a Chinese Wall under the pressure of rule $14 \mathrm{e}-3$, it will not be free from claims of liability for breach of fiduciary duty by the beneficiaries of its trusts. The Securities and Excliange Commission, recognizing this problem, stated that "depending on the circumstances, it may be appropriate [for a bank] to advise customers of its use of tlie Chinese Wall, because the institution would not be using all information that it had received to the benefit of a particular customer." 153 That a bank can obtain an implicit waiver of a fiduciary duty it owes to its trust beneficiaries by simply disclosing its intention not to fulfill completely its responsibilities is, at best, a doubtful proposition.

To minimize conflicts of interests, the administered wall is the best of the Chinese Wall alternatives available to a bank, but it is not a perfect solution. The procedures of the administered wall are complex and inay significantly burden the bank officers who are responsible for them, and its utility will not be fully estabhshed until it withstands challenge under rule 14e-3(d). Nevertheless, the administered wall has the significant advantage of preventing a bank's trust departinent from purchasing or selling a security when the bank has information that could indicate that the purchase or sale would be unwise.

\section{AIDER-AND-ABETTOR LIABILITY}

The inanagement of nonpublic information is only one of the problems a bank faces in dealing with public compamies. As banks participate in their customers' business transactions, they inay be hable as aiders and abettors of securities law violations that the customers commit. If the bank plays a routine role in a transaction-for example, paying checks drawn on the corporate account, or acting as transfer agent-the bank in all likelihood will not be liable as an aider and abettor. ${ }^{154}$ The crucial issue is the extent of the bank's knowledge of its borrower's illegal activities. ${ }^{155}$ Banks have access to substantial quanti-

153. 45 Fed. Reg, at 60,415 .

154. But $\mathcal{C}$. Carroll v. First Nat'l Bank of Lincolnwood, 413 F.2d 353, 358 (7th Cir. 1969) (reversing the trial court's dismissal of the complaint as to the bank on the ground that agents of the bank, acting with apparent authority, paid drafts against the plaintiffs' accounts with the bank, in connection with a fraudulent scheme by officers of the bank who acted outside the scope of their authority), cert. denied, 396 U.S. 1003 (1970).

155. See Ruder, Multiple Defendants in Securities Law Fraud Cases: Aiding and Abetting, Conspiracy, In Pari Delicto, Indemnification, and Contribution, 120 U. PA. L. REv. 597, 630-31 (1972). 
ties of information about their borrowers' activities and, by virtue of the covenants in the typical commercial loan agreement, have influence on their borrowers' activities. The bank's knowledge of or control over a custorner's illegal actions may give rise to aider-and-abettor liability.

\section{A. The Elements of the Offense.}

Aiding and abetting a securities law violation is a common law offense, created by the federal courts rather than by federal statute or rule. The elements of the offense derive from the Restatement of Torts and were initially formulated as follows: "Three elements are . . . required for liability: (1) that an independent wrong exist; (2) that the aider or abettor know of that wrong's existence; and (3) that substantial assistance be given im effecting that wrong."Is6 Clearly, a securities law violation committed by the bank's custoiner would satisfy the independent-wrong requirement. The elements of knowledge and substantial assistance are less clear, although they have been extensively discussed in a number of cases arising under the securities laws.

Courts have not agreed on the scope of the knowledge requirement. Some cases define an aider and abettor's knowledge as a "general awareness . . . that [the aider and abettor's] role was part of an overall activity that is improper," 157 but many decisions have defined the knowledge requirement flexibly. ${ }^{158}$ Some courts have even held

156. Landy v. FDIC, 486 F.2d 139, 162-63 (3d Cir. 1973), cert. denied, 416 U.S. 960 (1974). See RESTATEMENT (SECOND) OF TORTS $\$ 876$ (b) (1977).

157. E.g., Gould v. American-Hawaiian S.S. Co., 535 F.2d 761, 779 (3d Cir. 1976); Woodward v. Metro Bank of Dallas, 522 F.2d 84, 95 (5th Cir. 1975); SEC v. Coffey, 493 F.2d 1304, 1316 (6th Cir. 1974), cert. denied, 420 U.S. 908 (1975); SEC v. National Bankers Life Ins. Co., 324 F. Supp. 189, 195 (N.D. Tex.), affd per curiam, 448 F.2d 652 (5th Cir. 1971).

158. See, e.g., Rochez Bros. v. Rhoades, 527 F.2d 880, 886 (3d Cir. 1975). In Rochez Bros. a vice president and former shareholder alleged that the issuing corporation aided and abelted the securities violation of the issuer's president. The Court of Appeals for the Third Circuit noted in Rochez Bros. that

[i]t has been held that liability for aiding and abetting may be found on less than actual knowledge of the illegal activity . . . . How much or how little knowledge would seem to vary with the facts of each case. Courts that have considered the knowledge requirement have differed somewhat on its scope.

Id. (footnote and citations omitted). Cf. Gould v. American-Hawaiian S.S. Co., 535 F.2d 761, 780 (3d Cir. 1976) (a complaint charging aiding and abetting of a securities law violation is ordinarily insufficient if it fails to charge actual knowledge, but actual knowledge is not required when the alleged aider and abettor derives benefits from, and has either consciousness, or consiructive knowledge, of the violation); Woodward v. Metro Bank of Dallas, 522 F.2d 84, 95 (5th Cir. 1975) (a bank must possess more knowledge about a routime transaction to be held liable than it must possess about an unusual transaction). See also IIT, an Int'l Inv. Trust v. Cornfeld, 619 F.2d 909, 925-26 (2d Cir. 1980) (requiring that there be a conscious imtent to aid in the fraud in cascs in 
that reckless disregard of readily available evidence of fraud is the legal equivalent of actual knowledge of a securities law violation. ${ }^{159}$

The meanimg of "substantial assistance" to another party's securities fraud is also controversial. Some courts have rehed upon the $R e$ statement of Torts to determine whether the assistance rendered by an alleged aider and abettor is substantial. ${ }^{160}$ The relevant factors are: "(1) the amount of assistance given by the defendant; (2) his presence or absence at the time of the tort; (3) his relation to the other person; and (4) his state of mind."161

A body of case law has developed holding that a party may be hable as an aider and abettor for silence and inaction. An early aiderand-abettor case held that there was "not a scrap of authority supporting [the] extraordmary theory" that aider-and-abettor hability could be imposed "on anyone whose conduct consists solely of maction."162 Cases since then have held that silence can be substantial assistance when there is a duty to disclose. ${ }^{163}$ Even if a bank does not owe a duty of disclosure to a party, the bank may be hable for aiding and abetting a fraud by remainmg silent if, by its silence, the bank consciously in-

which the defendant's conduct consisted of an omission to speak or act, and in which the defendant had no independent duty to disclose).

159. Tucker v. Janota, [1979 Transfer Binder] FED. SEC. L. REP. (CCH) \ 94,711, at 94,716 (N.D. 1ll. 1978); Felts v. National Account Systems Ass'n, 469 F. Supp. 54, 66 (N.D. Miss. 1978); Lake v. Kidder, Peabody \& Co., [1978 Transfer Binder] FED. SEC. L. REP. (CCH) \ 96,509, at 93,974 (N.D. Ind. 1978) (the plaimtiff failed to prove either actual knowledge or recklessness); Stern v. American Bankshares Corp., 429 F. Supp. 818, 826-27 (E.D. Wis. 1977); cf. Edwards \& Hanly v. Wells Fargo Sec. Clearance Corp., 602 F.2d 478, 484-85 (2d Cir. 1979) (the court stated in dictum that recklessness may substitute for actual knowledge of a securities violation only when the defendant has a "special relationship" with the plaintiff that is "fiduciary in nature"), cert. denied, 444 U.S. 1045 (1980).

160. See, e.g., Monsen v. Consolidated Dressed Beef Co., 579 F.2d 793, 800 (3d Cir.), cert. denied, 439 U.S. 930 (1978); Landy v. FDlC, 486 F.2d 139, 163 (3d Cir. 1973), cert. denied, 416 U.S. 960 (1974); Saltzinan v. Zern, 407 F. Supp. 49, 57 (E.D. Pa. 1976); Odette v. Sliearson, Hammill \& Co., 394 F. Supp. 946, 960 (S.D.N.Y. 1975). See RESTATEMENT (SECOND) OF TORTS $\S 876(\mathrm{~b})$ (1977).

161. Landy v. FDIC, 486 F.2d 139, 163 (3d Cir. 1973), cert. denied, 416 U.S. 960 (1974).

162. Wessell v. Buhler, 437 F.2d 279, 283 (9th Cir. 1971).

163. See, e.g., Edwards \& Hanley v. Wells Fargo Sec. Clearance Corp., 602 F.2d 478, 484 (2d Cir. 1979), cert. denied, 444 U.S. 1045 (1980). See generally IIT, an lnt'l Inv. Trust v. Comfeld, 619 F.2d 909, 925-27 (2d Cir. 1980); Woodward v. Metro Bank of Dallas, 522 F.2d 84, 96-97 (5th Cir. 1975). But see Ruder, supra note 155, at 644 (contending that silence when a duty to disclose exists is a basis for finding primary liability, not secondary liability as an aider and abettor).

One problem with the duty-to-speak formulation in the cases cited above is that it is difficult to determine with foresight when or to wlom a duty to speak exists, because that duty often arises out of a special relationship between the plaintiff and the alleged aider and abettor. A bank may have special relationships with various parties, such as its customers, imvestors, and loan participants, any of whicl, in a particular factual context, may allege a breach of duty based upon the bank's silence. 
tended to render assistance to a fraud ${ }^{164}$ or to derive a benefit therefrom. ${ }^{165}$

\section{B. Implications for Commercial Lenders.}

A brief consideration of some common and not-so-common business situations will help illustrate the relevance of the principles described above to commercial lenders.

1. Covenant to Maintain Subordinated Debt. A bank is asked to lend money to a corporate borrower. In reviewing the borrower's balance sheet the bank notices an item of hundreds of thousands of dollars in unsecured debt. The borrower explains that for many years it has operated a savings program in which the borrower's employees buy the borrower's unsecured proinissory notes, relying solely on the integrity and financial soundness of their einployer. The borrower has never shown financial statements to its employees in connection with its savings program, nor have the notes been registered under the Securities Act of 1933.166

The bank agrees to make the loan on the condition that the savings program be continued and that the company subordmate all debt incurred in the savings prograin to the borrower's obligations to the bank. Despite the borrower's objection that if it subordmates the notes, the employees will no longer buy them, the bank makes a secured loan, effectively subordinating the unsecured notes.

In the three and one-lialf years that follow, the borrower's financial condition declines. Finally the bank is forced to foreclose on its collateral and apply the proceeds to the borrower's outstanding debt to the bank. The borrower fails to pay the notes issued to its employees under the savings program.

164. IIT, an Int'l Inv. Trust v. Cornfeld, 619 F.2d 909, 926-27 (2d Cir. 1980); Monsen v. Consolidated Dressed Beef Co., 579 F.2d 793, 800 (3d Cir.), cert. denied, 439 U.S. 930 (1978); Gould v. American-Hawaiian S.S. Co., 535 F.2d 761, 780 (3d Cir. 1976); Rochez Bros. v. Rhoades, 527 F.2d 880, 889 (3d Cir. 1975); SEC v. Coffey, 493 F.2d 1304, 1317 (6th Cir. 1974); cf. Hochfelder v. Midwest Stock Exch., 503 F.2d 364, 374 (7th Cir.) (inaction coupled with affirmative conduct), cert. denied, 419 U.S. 875 (1974); Brennan v. Midwestern United Life Ins. Co., 417 F.2d 147, 154 (7th Cir. 1969) (acquiescence through silence combined with affirmative acts), cert. denied, 397 U.S. 989 (1970).

165. See Monsen v. Consolidated Dressed Beef Co., 579 F.2d 793 (3d Cir.), cert. denied, 439 U.S. 930 (1978). Although the Court of Appeals for the Third Circuit held that the bank rendered substantial assistance to a rule 10b-5 violation by its silence and inaction, a key fact underlying the decision was the bank's self-interest in encouraging its client to borrow from the client's employees on a subordinated basis while the bank was a secured creditor. See also Green v. Jonhop, Inc., 358 F. Supp. 413 (D. Or. 1973) (the silence and inaction of an issuer, which had knowledge of misleading sales and earnings projections by its market maker and principal underwriter, encouraged investors to rely on such projections).

166. 15 U.S.C. $\$ \S 77 \mathrm{a}-77 \mathrm{bbbb}(1976)$. 
On facts substantially like these, the Court of Appeals for the Third Circuit in Monsen v. Consolidated Dressed Beef Co. ${ }^{167}$ affirmed a jury verdict that held a bank liable as an aider and abettor of its customer's fraud. The court found evidence of liability in a "combination of knowledge and action by the Bank."168 The bank not only required that the company subordinate the notes held by the employees, but also knew that the company did not intend to disclose this fact to the employees. Altlough either eleinent alone might not have been enough, togetlier they sufficed to show the bank's complicity as an aider and abettor.

2. Raising Additional Capital Through an Offering of Securities. The borrower is in poor financial condition and requires additional workmg capital. The bank warns the borrower that unless it improves its financial condition the bank will terminate its credit arrangements. With the bank's knowledge, the borrower engages in a private placement of preferred stock. In connection with the offering, the bank agrees to waive all existing defaults of the borrower under the credit arrangement between the bank and the borrower. The bank refuses, however, to modify the loan agreement or waive any future violations.

As the loan agreement requires, the borrower shows the bank all offering literature used in the private placement. The private placement memorandum discloses neither past defaults and waivers under the bank loan nor the troubled state of the relationship between the bank and the borrower. An officer of the bank reviews the offering inemorandum but does not insist on any changes.

Six months after the offering is completed, after the borrower has continued to mcur operating losses, the bank calls a default and realizes on its collateral. The purchasers of the preferred stock then sue the borrower for violating rule $10 \mathrm{~b}-5$ and sue the bank for aiding and abetting that violation.

If a reasonable investor would have found the oinitted information material, the bank inay be liable as an aider and abettor if there is a purchaser to whom the bank owed a duty of disclosure because of a fiduciary relationship or if the bank consciously intended to assist the issuer in its fraud by remaining silent after it learned of the facts giving rise to the violation of rule $10 \mathrm{~b}-5 .{ }^{169}$

167. 579 F.2d 793 (3d Cir.), cert. denied, 439 U.S. 930 (1978).

168. Id. at 802 .

169. "Conscious intent" on the part of a corporate defendant inay be shown by circumstantial evidence. SEC v. Coffey, 493 F.2d 1304, 1317 (6th Cir. 1974). The derivation by the bank of a financial benefit from the transaction might show such an intent. 
3. The Leveraged Tax Shelter. A company raises capital for its oil and gas drilling ventures by forming and selling interests in limited partnerships. The partnership interests are attractive to investors because a bank is willing to give them non-recourse financing, which increases the investor's tax basis in his partnership interest and therefore increases his allowable tax deductions.

The partnership passes the capital raised in its offering of himited partnership interests to the drilling company, which uses the money to purchase certificates of deposit of the bank that made the non-recourse loan. The source of funds for the company's drilling ventures is the cash generated by successive private placements of limited partnership interests in successive drilling programs. After it has participated in these financings for seven years, the bank is advised by counsel to cease doing so. It declines to finance the current drilling program; for a fee it finds anotlier bank to provide the loan.

The proinoters of the current limited partnership tell investors that the bank had financed the prior drilling prograins. They do not claim that the bank is financing the current one. As the bank has no direct involvement in the transaction, it does not review the prospectus for the current drilling program. Shortly after the current placement is completed, the parent drilling company files for voluntary bankruptcy. Investors in the current drilling program sue the promoters, the bank, and its officers under section 12(2) of the Securities Act of $1933^{170}$ and section 10(b) of the 1934 Act. ${ }^{171}$ The bank and the officers move for dismissal, alleging that the complaint fails to state a claim upon which relief can be granted.

In Vogel v. Trahan 172 the court denied such a motion. Notwithstanding the uncontroverted affidavits of the bank officers that neither they nor the bank had any direct involvement in the current offering, in which all plaintiffs had invested, the court ruled that they could be held liable as aiders and abettors. ${ }^{173}$ The district court did not explain its reasoning. Arguably the decision is incorrect.

4. "Shark Repellant." A dissident shareholder group has announced that it will wage a proxy contest with management for control of a coinpany. Management requests a loan from the bank to estabhsh

170. 15 U.S.C. $\$ 77 /(2)(1976)$

171. 15 U.S.C. $\$ 78 \mathrm{j}(\mathrm{b})(1976)$.

172. [1980 Current Binder] FED. SEC. L. REP. (CCH) \ 97,303, at 97,075 (E.D. Pa. 1980). A motion to disıniss the bank on grounds of improper venue under the National Bank Act of 1864, ch. 106, 13 Stat. 99 (codified in scattered sections of 12, 19, 31 U.S.C.), however, was granted.

173. [1980 Current Binder] FED. SEc. L. REP. (CCH) at 97,083 . 
an Employee Stock Ownership Plan. Management advises the bank that it is initiating the plan to strengthen its hand in the forthcoming proxy fight.

In connection with the proposed loan, the bank requests and receives management's draft proxy statement. The bank's counsel reviews the proxy statement and advises the bank that it contams several material deficiencies. The bank and its counsel call management and its counsel and advise them of the deficiencies in the draft proxy stateinent. Management agrees to make the necessary corrections, and the bank makes the loan on management's assurances that it will make the changes. The changes are not made or are inadequately made. The dissident shareholders sue management under section 14 of the 1934 Act ${ }^{174}$ for making a false and fraudulent proxy solicitation and sue the bank for aiding and abetting that violation. Although there was an independent securities law violation and knowledge of the potential for it by the bank, there was probably no substantial assistance in the violation. The bank spoke up in an effort to prevent the violation and clearly did not consciously intend that a false proxy statement be distributed to shareholders. At worst, the bank was negligent im failing to police management's correction of its proxy statement. Whether that negligence is enough to hold the bank liable as an aider and abettor under section 14 remains to be seen.

\section{Bank Precautions to Avoid Liability.}

As indicated above, banks that have financing arrangements with public companies or comparnes engaged in securities transactions may often find themselves in situations that could result in aider-and-abettor liability. Banks that do not choose to withdraw totally from this field must therefore scrutinize the transactions they finance. The paradox in this area of the law, however, is that the more a bank learns, the greater the likelihood that it can be held hable for the conduct of its borrower. The solution for a bank is to voice quickly any objection it has to the unlawful conduct of its customers.

\section{CONCLUSION}

Banks have increasingly been joined as defendants in suits brought under the securities laws because of their involvement in the transactions of publicly-held corporations. Many of the alleged violations arise from the banks' use of nonpublic information that customers give in connection with commercial banking activities. A bank is not dis-

174. 15 U.S.C. $\$ 78 \mathrm{n}(1976)$. 
qualified from dealing with conipanies that contemplate acquiring another customer about which the bank possesses confidential information. Yet the bank risks violating the securities laws and breaching common law duties if it discloses the confidential information to the acquiring conipany. Courts are not in accord, inoreover, about whether a bank inay use the inforination internally in deciding whether to finance the acquisition.

Another risk that a bank faces is hability for its trnst department's using confidential infornation obtained from commercial department customers. To avoid this conflict, soine banks have estabhished Chinese Walls that cut off the fiow of confidential information from the cominercial department to the trust department. This solution is not satisfactory because the trust department, as a professional trustee, has an obligation to use all the information at the disposal of the bank in making its investntent decisions, as long as the use of the information is not illegal. Although a breach of confidentiality may violate the securities laws if the imformation so obtained is used in connection with a decision to buy or to sell securities, the use of the information is legal in a decision not to buy or not to sell securities. The advocates of the Chinese Wall overlook the trustee's duty to make all legal uses of confidential information. The recent adoption by the Securities and Exchange Commission of an antifraud rule for tender offers may require banks to establish Chinese Walls to avoid hability under the rule. Establishing a Chinese Wall under the pressure of this rule, however, does not remove the problenus of the conflicting duties that proinpt the creation of a Chinese Wall.

A final area of concern is potential aider-and-abettor hability of a bank for its customers' securities law violations. Banks have been held liable both when they have remamed silent after learning of a customer's fraud, and when they have actively furthered the fraud. The only clear way for a bank to avoid aider-and-abettor hability is to protest such conduct immediately and, if necessary, terminate its relationship witl a customer that is violating the securities laws. 